\title{
Azahelicenes and other similar tri and tetracyclic helical molecules
}

\author{
Florea Dumitrascu, ${ }^{\text {a }}$ Dan G. Dumitrescu, ${ }^{\text {a }}$ and Ioana Aron ${ }^{\text {b }}$ \\ ${ }^{a}$ Center for Organic Chemistry C.D. Nenitescu, Romanian Academy 202 B, Spl. \\ Independentei,060023, Bucharest, Romania \\ ${ }^{b}$ Roy and Diana Vagelos Laboratories, Department of Chemistry, University of Pennsylvania, \\ Philadelphia, Pennsylvania 19104-6323 \\ E-mail:fdumitra@yahoo.com
}

\begin{abstract}
The possibility of using a wide range of synthetic methods and the diverse properties resulted in an increased interest in azahelicenes and similar nitrogen bearing helical molecules. The aim of this paper is to provide an update to the recent reviews, while also including tri and tetracyclic helical molecules.
\end{abstract}

Keywords: Azahelicenes, helical chirality

\section{Table of Contents}

1. Introduction

2. Synthetic Methods

2.1 Central linkage

2.1.1 Photochemical cyclization

2.1.2 Sn and Pd mediated couplings

2.1.3 Syntheses for dictyodendrins and related substituted pyrrolo[2,3-c]carbazoles

2.1.4 Syntheses of helical scaffolds containing one or more $\mathrm{N}-\mathrm{N}$ bonds

2.1.5 [2+2+2] Trimerization reactions

2.1.6 Sulfination of bisindole derivatives

2.1.7 Consecutive Knoevenagel condensation/Diels-Alder cycloaddition

2.2 Side annulation or substituent insertion

2.2.1 Oxidation reactions

2.2.2 N-ylide 1,3-dipolar cycloadditions

2.2.3 The reactions of acetylenic esters with tricyclic azines

2.2.4 Helical molecules built from $p$-substituted benzene

2.2.5 Helical molecules built from 1,2,3-trisubstituted benzene 
2.2.6 Diels-Alder cycloaddition reactions

2.2.7 Synthesis of expanded azahelicenes

3. Properties

4. References

\section{Introduction}

The helical intramolecular distortion of ortho annulated cyclic or heterocyclic compounds is caused by sterical overcrowding in the molecule due to the number of rings or to the number and volume of the ortho substituents. In the case of helicenes or heterohelicenes the minimum requirement for helicity to occur is the existence of five ortho annulated rings.

In 1971 Wynberg formally included phenanthrene and benzo[c]phenanthrene in the class of helicenes and stated that properly positioned substituents may infer helicity to the molecule. ${ }^{1}$ Lately, the field of azahelicenes has received a great deal of interest. Several reviews on carbohelicenes are available, ${ }^{3}$ as well as a comprehensive review on aza and azonia helicenes published by Sato and Arai. ${ }^{2}$ This work will provide an update to the field of aza and azonia helicenes, including the related tri and tetracyclic helical molecules containing nitrogen atoms.

In the approach towards aza and polyaza helical molecules two main synthetic strategies are used. The first strategy, central linkage approach, consists in building the molecule from several ring systems connected via short chains and coupling these parts either using photocyclization or another coupling procedure. This is similar to the classical route for helicenes first reported by Newman in 1955 (Scheme 1). ${ }^{4}$

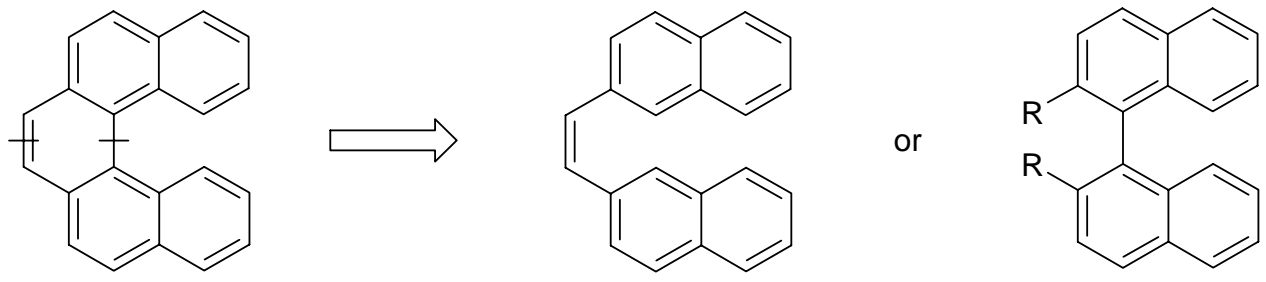

\section{Scheme 1}

The second synthetic approach, ortho annulation or substituent insertion, uses formal helicenes such as phenanthrene or phenanthroline (and in some cases even benzene) as starting materials. The final helical system is obtained by building successive rings or inserting one or several bulky substituents in the ortho positions of the initial molecule (Scheme 2). 
<smiles>C1=CC2=CC=c3ccc4ccccc4c3=c3c2cccc3=C1</smiles><smiles>[R]c1ccccc1-c1c([R])ccc([R])c1-c1ccccc1[R]</smiles><smiles>[R]C=C[R]</smiles>

\section{Scheme 2}

\section{Synthetic Methods}

\subsection{Central Linkage}

2.1.1 Photochemical cyclizations. Caronna et al. ${ }^{5}$ adapted the classical helicene synthesis of stilbene derivative photocyclization to obtain aza or diaza[5]helicenes. The key intermediates, ethylenes substituted in the 1- and 2-positions with quinoline or isoquinoline, $\mathbf{1}$, were synthesized using a Wittig condensation between the corresponding aldehydes and phosphonium salts. In the case of symmetrical ethylenes, the heterocyclic aldehydes were reduced to the corresponding alcohols, transformed into chlorides and used to obtain the corresponding phosphonium salts for the Wittig reaction.

The final stage, the photocyclization of ethylene derivatives 1 to mono or diaza [5]helicenes 2 takes place generally in very good yields and without the formation of corresponding nonhelical isomers (Scheme 3).
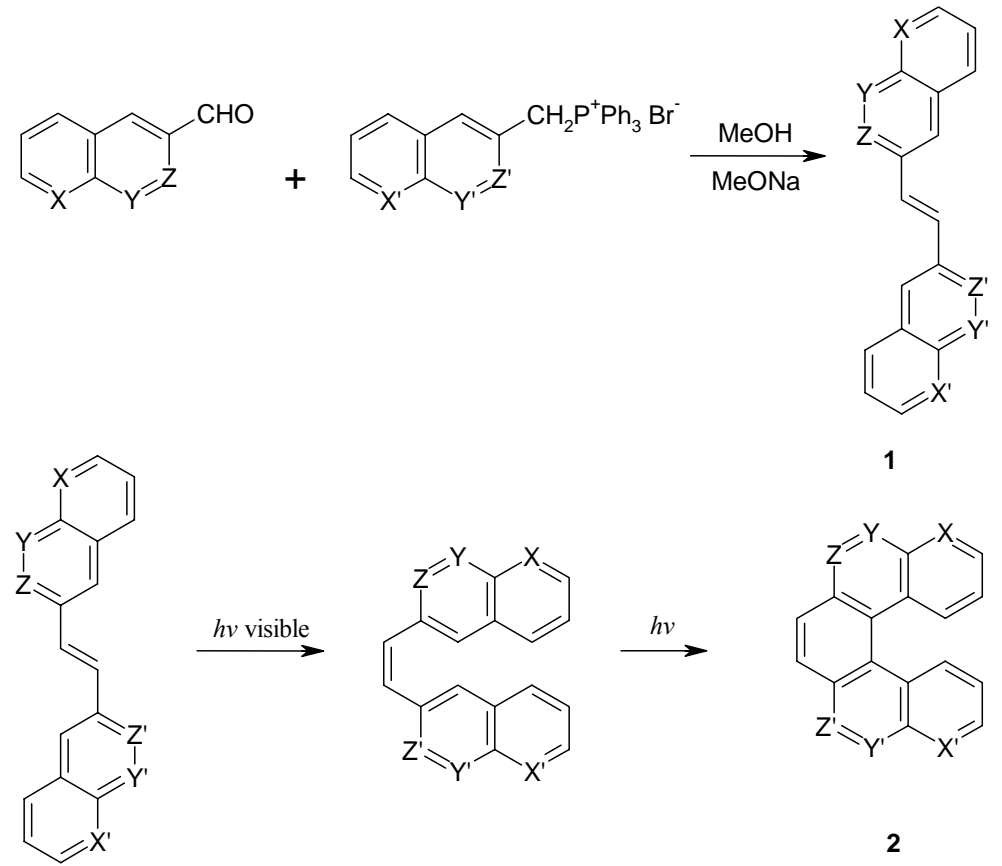<smiles>[X][Y]1cc2ccc3[Z]:[Y]c([Y])c3c2c2ccccc12</smiles>

Scheme 3 
This pathway offers high yields, regioselectivity and can be applied in the synthesis of a wide range of aza and diaza[5]helicenes. However, some monoaza[5]helicenes could not be obtained using this method. The photochemical cyclization leading to 7-aza[5]helicene $\mathbf{4}$ was unsuccessful, whereas the attempt to obtain 2-aza[5] helicene gave the 7-azabenzo[ghi]perylene 3 as the only product (Scheme 4).<smiles>C(=C\c1ccc2ccccc2c1)\c1ccc2ccccc2c1</smiles>

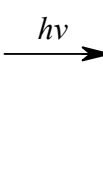<smiles></smiles>

3<smiles>C(=N\c1ccc2ccccc2c1)\c1ccc2ccccc2c1</smiles><smiles>CC(C)(C)C(C)(C)C</smiles><smiles>c1ccc2c(c1)ccc1ccc3cnc4ccccc4c3c12</smiles>

4

\section{Scheme 4}

In order to complete the series of monoaza[5] helicenes, Caronna et al. ${ }^{6}$ revised their initial synthetic approach. As the final photocyclization step showed both high yields and regioselectivity, the method was applied on different key intermediates. Thus, instead of 1,2disubstituted ethylenes with naphthyl, quinoline or isoquinoline moieties, derivatives with three ortho-condensed rings on one side of the ethene and one ring on the other side were used. Also, the regioselectivity of the final photocyclization step was explained using ab initio computational methods.

Both possible approaches were investigated for the synthesis of 1-aza and 3-aza[5]helicene: using pyridine as the nitrogen bearing moiety and phenanthrene as the tricyclic ring system, and using benzene as the single ring and benzo[ $[h]$ isoquinoline as the nitrogen bearing moiety. 1Aza[5] helicene 5 was obtained along with 3-aza[5] helicene 6 in a 9:1 and 1:9 ratio respectively, depending on the method used (Scheme 5). ${ }^{6}$ 


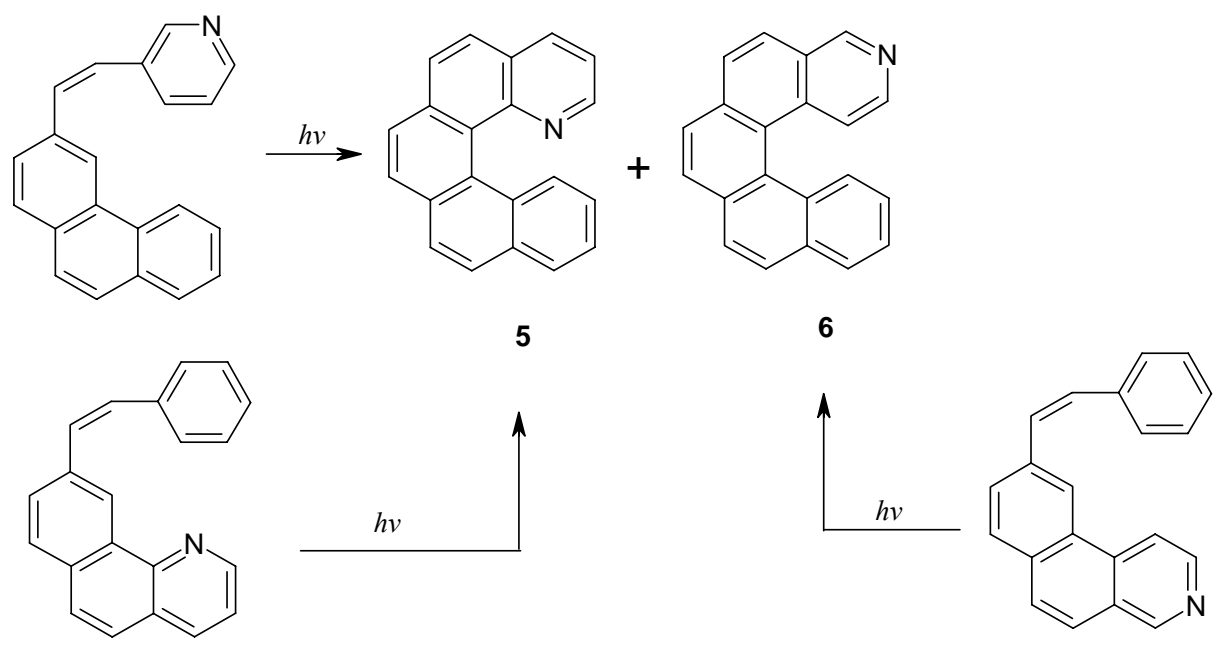

\section{Scheme 5}

Ben Hassine et al. ${ }^{7}$ expanded the original synthesis published by Caronna for the unsubstituted 3-aza[6]helicene 7. The synthesis involves two Mizoroki-Heck coupling reactions, each followed by a photocyclization step, with an overall yield of $26 \%$ for compound 7 (Scheme 6). The final photocyclization step is not completely regioselective, a small amount of isomeric 1-aza[6]helicene 8 being isolated.

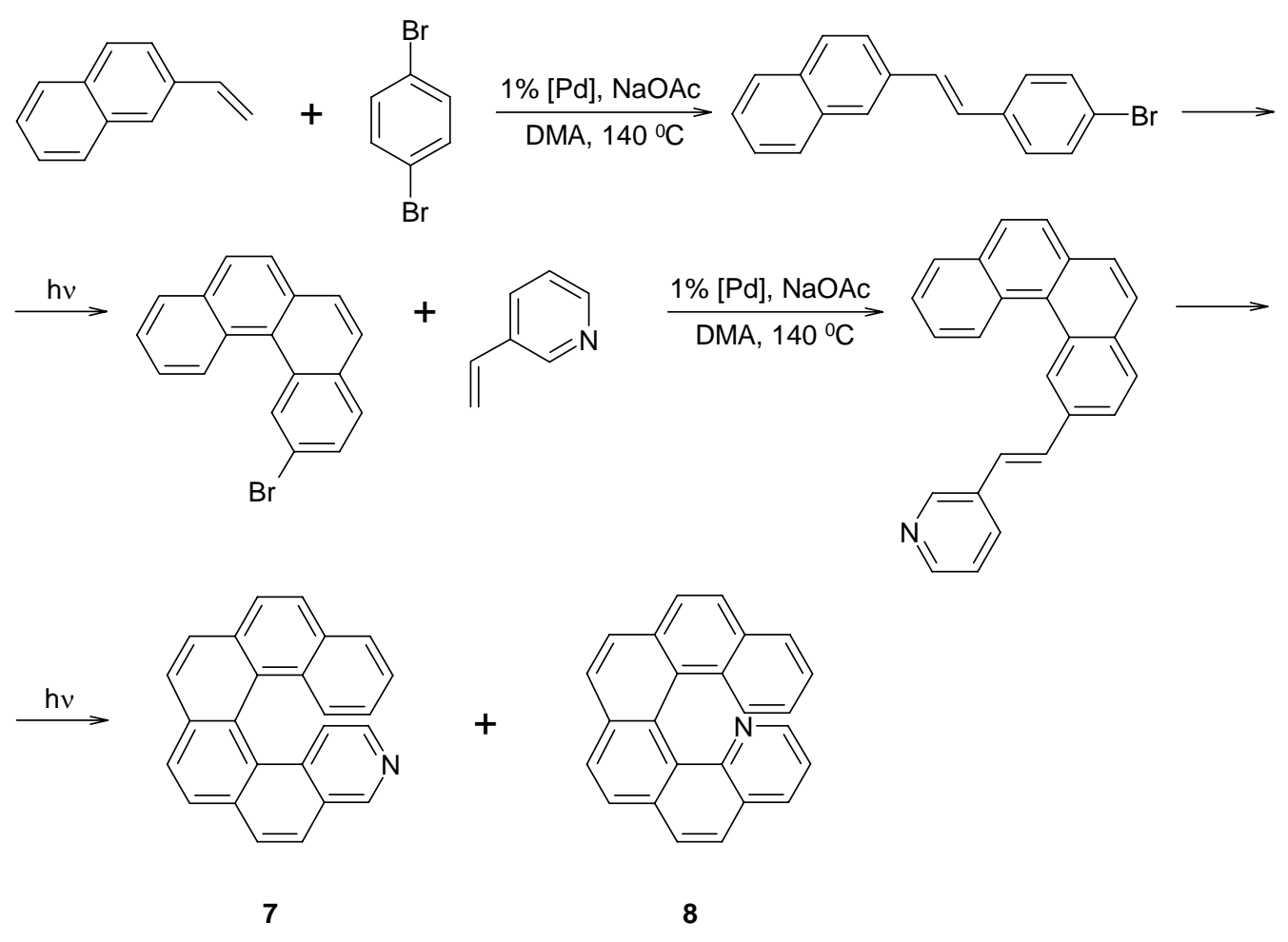

\section{Scheme 6}


In order to continue their series of azoniahelicenes, Sato and Arai ${ }^{8}$ employed a double photocyclization of disubstituted ethylenes in the synthesis of hexa- and heptacyclic thiaazoniahelicenes 9 and 10. For both compounds, the first part of the synthesis involves obtaining the thiaazonia tetracyclic moiety and condensing it with benzaldehyde for helicene 9 or 2-naphthaldehyde for $\mathbf{1 0}$ (Scheme 7).<smiles>CC(=O)c1cc2ccccc2s1</smiles><smiles>Cc1cc[n+](C=Cc2cc3ccccc3s2)cc1</smiles><smiles>COC(OC)c1cccc2c1sc1cc[n+]3ccc(C)cc3c12</smiles><smiles>CC(C)N(C)C</smiles>

9<smiles>FC(F)(F)c1ccc2ccc3ccc4ccccc4c3c2c1-c1cccc2sc3ccccc3c12</smiles>

10

\section{Scheme 7}

Special attention should be given to the very versatile synthetic method developed by Castle and co-workers 9 , based on the condensation and subsequent photochemical cyclization of 2carboxoyl chloride-3-chloro 3,4-annulated thiopenes with aromatic amines.

Using this method, thiaaza pentahelicene 11 was obtained by condensing 1chloronaphtho[2,1-b]thiophene-2-carboxoyl chloride with methoxy-substituted anilines, followed by photocyclization of the resulting products (Scheme 8). Derivatives 11 were also subjected to a wide range of chemical transformations. 


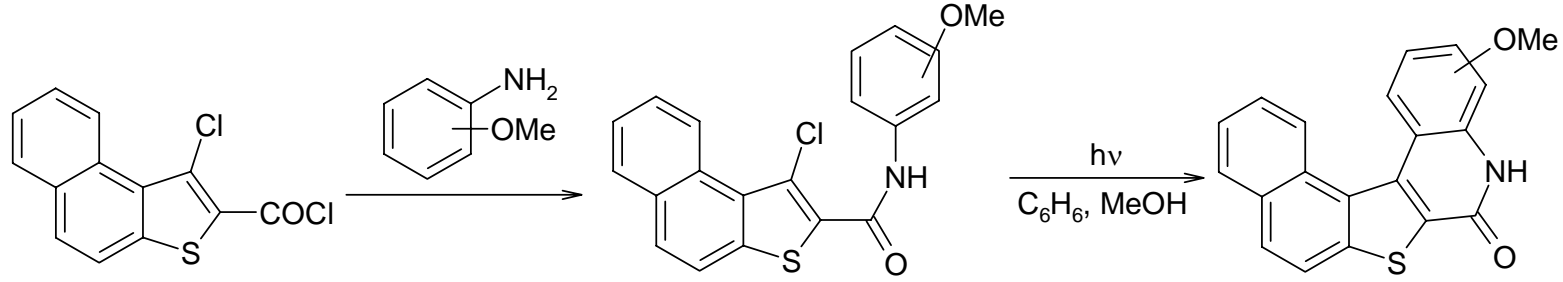

11

\section{Scheme 8}

Triazolo pentacyclic helicene $\mathbf{1 2}$ was obtained using the same synthetic strategy, by reacting 3-chloro-benzo $[b]$ thiophene-2-carbonyl chloride with 4-aminophenanthrene. The final stage, formation of the terminal triazole ring, occurred after reacting the corresponding hydrazine derivative with triethyl orthoformate (Scheme 9). ${ }^{10}$

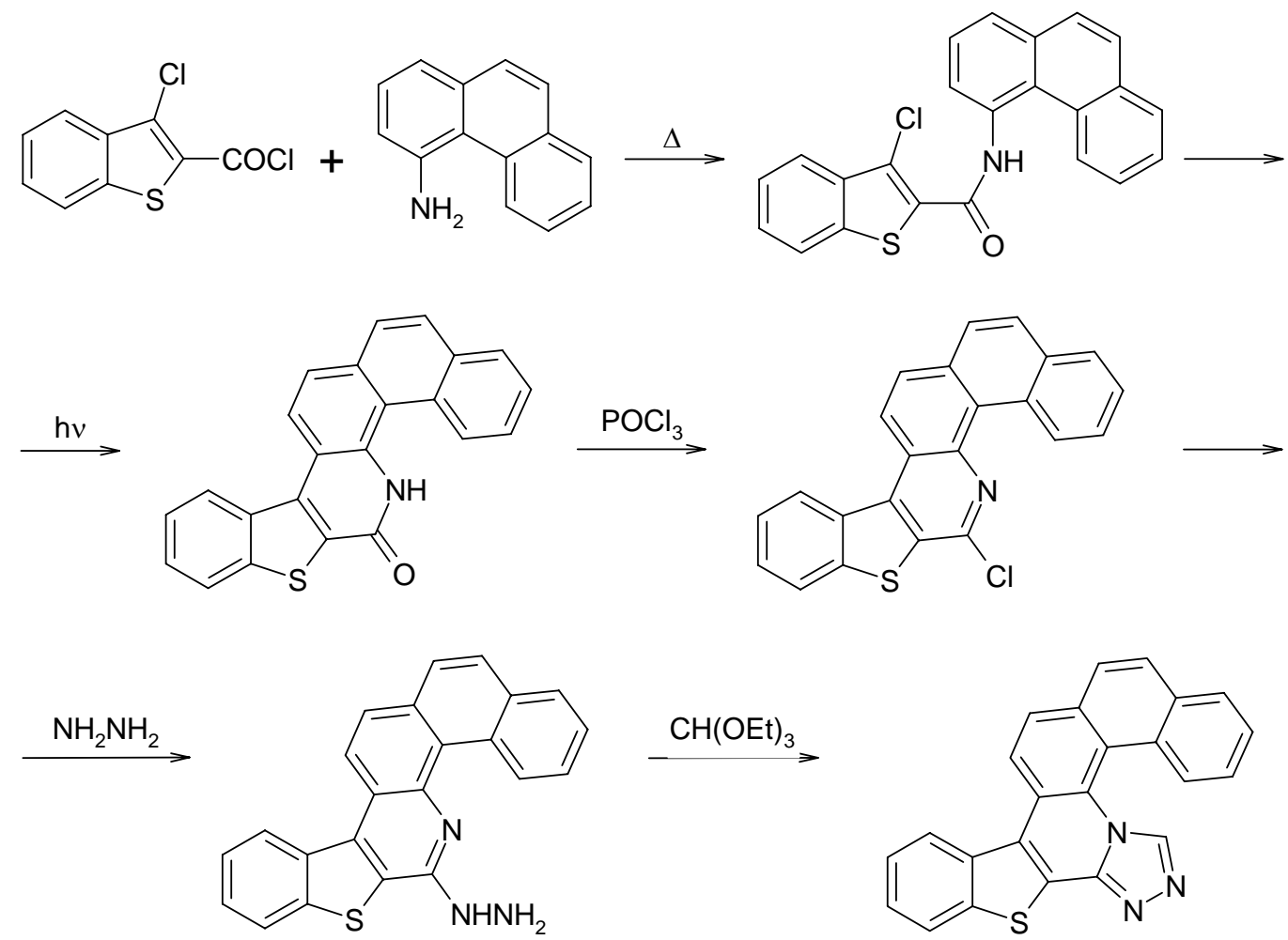

12

\section{Scheme 9}

By applying the photochemical approach on disubstituted $D$-camphor substituted benzodithiophene and thienoquinoline ethylenes, Osuga and co-workers ${ }^{11}$ obtained optically pure 
$(M)$ and $(P)$ thiaazahelicenes 13. The disubstituted ethylenes were prepared via a Wittig condensation. The photochemical stage resulted in 37:63 diastereomeric ratio, and the products were separated using column chromatography on silica gel (Scheme 10). Their enantiomeric purity was measured using HPLC chromatography and their absolute configuration using circular dichroism.<smiles>CC1(C)C2CCC1(C)C(O)C2NC(=O)c1cc2c(ccc3sc(C=O)cc32)s1</smiles>
$\downarrow a, b$<smiles>CC1(C)C2CCC1(C)C(O)C2NC(=O)c1cc2c(ccc3sc(/C=C/c4cc5c(ccc6ncccc65)s4)cc32)s1</smiles><smiles>C1CCCC1</smiles>

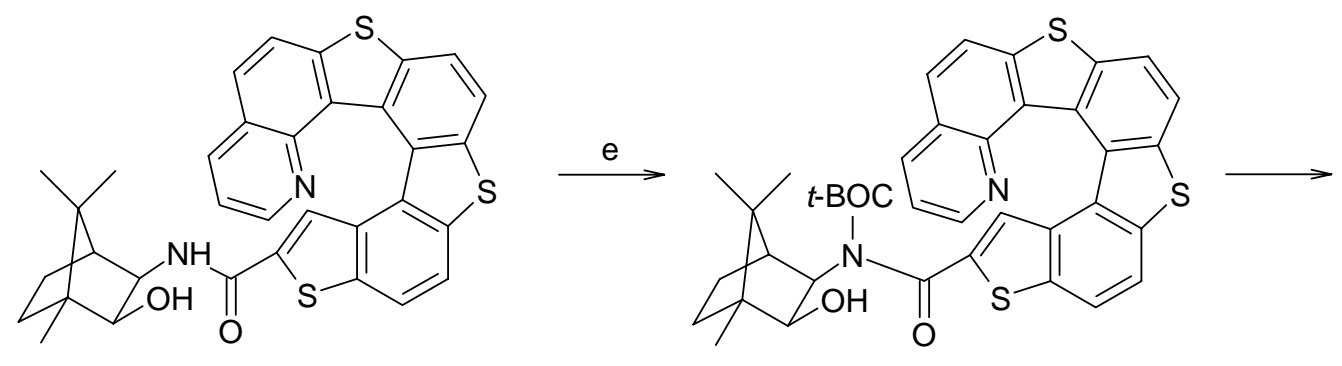

f, g, h<smiles>OCc1cc2c3c(ccc2s1)Sc1ccc2c-3c1-c1c(ccc3cccnc13)S2</smiles>

$(P)-(+)-13$<smiles>OCc1nc2c(ccc3sc4ccc5sc6ccccc6c5c4c32)s1</smiles>

$(M)-(-)-13$

a. $t$-BuOK, THF, methanol; b. triisopropylsilyl trifluoromethane sulfate, 2,6-lutidine, $\mathrm{CH}_{2} \mathrm{Cl}_{2}$; c. $\mathrm{I}_{2}$, propylene oxide, $\mathrm{Ar}, \mathrm{C}_{6} \mathrm{H}_{6}$; d. TBAF, THF; e. di-t-butyl dicarbonate, DMAP, $\mathrm{CH}_{2} \mathrm{Cl}_{2}$; f. HPLC separation; g. EtSLi, THF; h. $\mathrm{LiAlH}_{4}$, THF.

\section{Scheme 10}


2.1.2 Sn and Pd mediated couplings. As the photochemical cyclization method could not be used for the synthesis of 2-aza[5]helicene 14, the only product formed being 7azabenzo[ghi]perylene $\mathbf{3}$, a different approach was used, a $t$ - $\mathrm{Bu}_{3} \mathrm{SnH}$ mediated coupling (Scheme 11). ${ }^{6}$<smiles>Brc1ccccc1/C=C\c1ccc2ccc3ccncc3c2c1</smiles><smiles>CC(C)(C)CCCCC[SbH2]C(C)(C)C</smiles>

14

\section{Scheme 11}

Harrowven and coworkers ${ }^{12}$ developed a versatile synthetic method based on a $\mathrm{Bu}_{3} \mathrm{SnH}$ mediated coupling and selective homolysis of the carbon-iodine bond by 1,1 'azobis(cyclohexanecarbonitrile) (VAZO). This method was successfully applied in the high yield synthesis of 6-chloro-5-aza[5]helicene 15, using cooperative ortho effects to control the regioselectivity of the Wittig reaction and a halide atom as a protecting group in the homolytic aromatic substitution (Scheme 12).<smiles>BrCc1ccc2ccccc2c1I</smiles><smiles>COCCOCCOCc1cc2ccccc2nc1Cl</smiles><smiles>Clc1nc2ccccc2cc1/C=C\c1ccc2ccccc2c1I</smiles>

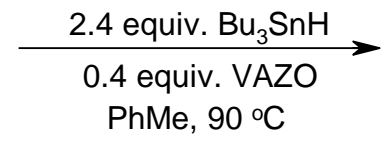<smiles>Clc1nc2ccccc2c2c1ccc1ccc3ccccc3c12</smiles>

\section{Scheme 12}


Nakano et al. ${ }^{13}$ used Pd complexes with xantphos and biphenyl-phosphine to catalyze coupling reactions on a variety of 2,2'-disubstituted 1,1'-diphenanthrenes. This synthesis could be applied only for obtaining the racemic aza[7]helicene $\mathbf{1 6}$ from the reaction of aniline with racemic 4,4'-biphenanthryl-3,3'-ylene ditriflate (Scheme 13).

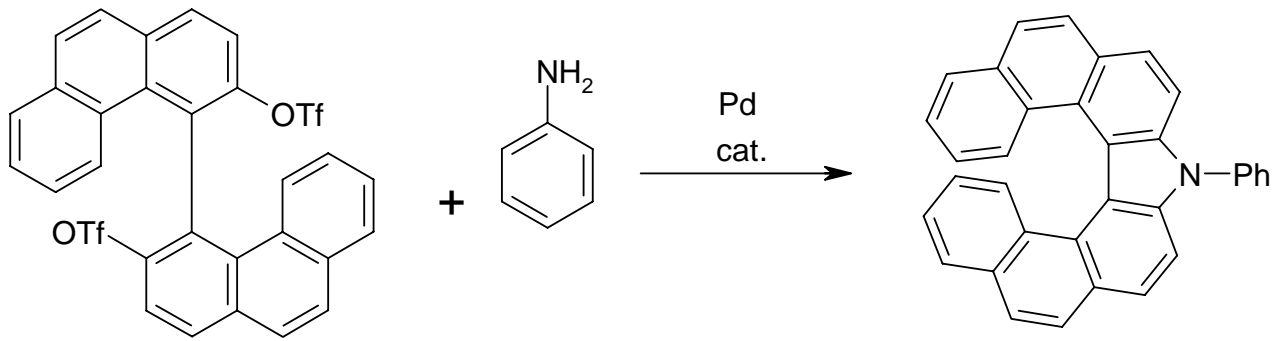

16

\section{Scheme 13}

2.1.3 Syntheses of dictyodendrins and related substituted pyrrolo[2,3-c]carbazoles. First isolated by Sato and co-workers ${ }^{14}$ in 1993 from the marine sponge Dictyodendrilla, the tetracyclic compounds 17 , dictyodendrins, were shown to possess potent aldose reductase inhibitory action. A representative compound was characterized by X-ray analysis and shown to exhibit helical chirality.

Later, a group led by $\mathrm{Warabi}^{15}$ isolated and characterized new such compounds from the same marine source, thus expanding the class of dictyodendrins from A to E (Scheme 14). It is noteworthy that these compounds exhibit complete telomerase inhibitory action even at concentrations as low as $50 \mu \mathrm{g} / \mathrm{L}$, making them suitable carcinostatics.

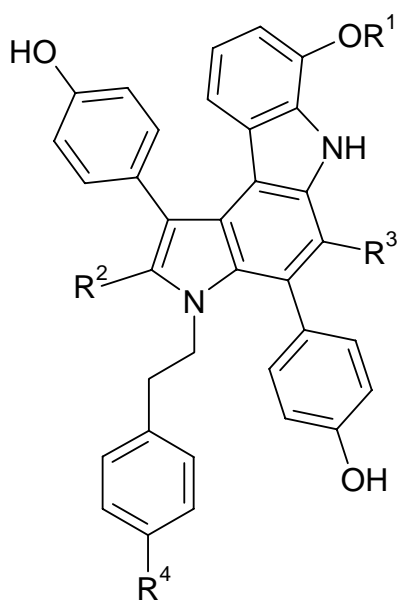

17

\section{Scheme 14}


Furstner and coworkers described the total synthesis of dictyodendrin B $\mathbf{1 8}^{16}$ and, in another paper, the total synthesis of dictyodendrins $\mathrm{C}$ and E. ${ }^{17}$ The synthesis of dictyodendrin $\mathrm{B}$ consists of 13 steps, affording the target compound in an $8 \%$ overall yield.

The key steps are the titanium catalyzed synthesis of the 2,3,7-trisubstituted indole ring and the photochemical cyclization and concomitant aromatization using $\mathrm{Pd} / \mathrm{C}$ in nitrobenzene leading to the substituted pyrrolo[2,3-c]carbazole scaffold in multigram quantities. For compound 18, the final procedure, the exhaustive demethylation without removing the labile sulfate group was performed using $\mathrm{BCl}_{3} /(n \text {-Bu })_{4} \mathrm{NI}$. Obtaining dictyodendrins $\mathrm{C}$ and $\mathrm{E}$ involves the same synthesis of the pyrrolo[2,3-c]carbazole system, followed by very selective chemical transformations to yield the desired substituents (Scheme 15).

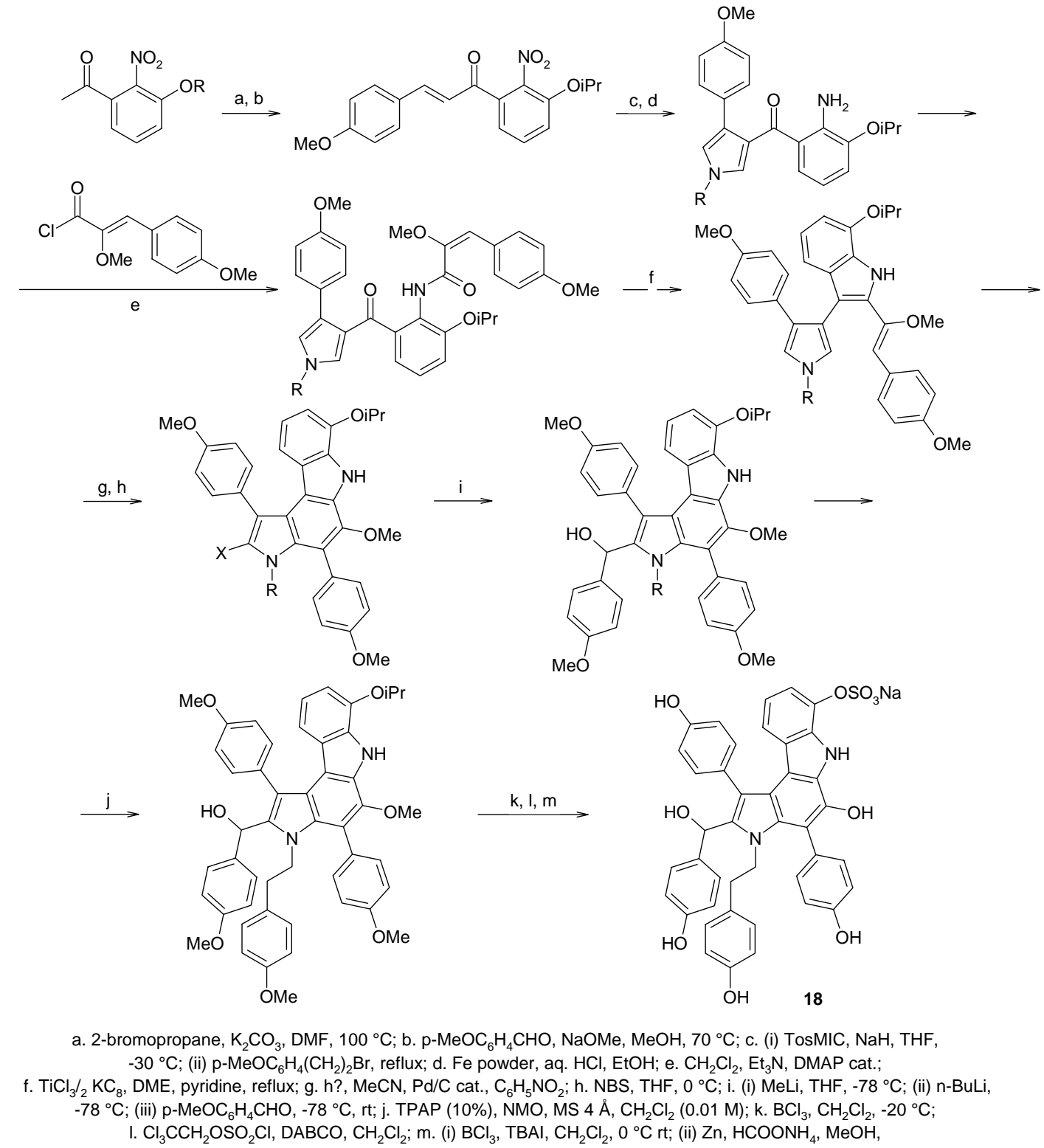

\section{Scheme 15}


Alvarez et al. ${ }^{18}$ recently put forward a similar synthesis for obtaining substituted pyrrolo[2,3-c]carbazole derivatives to that described by Furstner. The synthetic pathway is based on a Suzuki coupling leading either to 2-ethenyl-3-pyrrolo indole derivatives or to indole and pyrrole substituted ethylenes. The final photocyclization stage results in pyrrolo[2,3-c]carbazoles $\mathbf{1 9}$ in the case of pyrrole-substituted indoles or in isomeric $\mathbf{2 0}$ and $\mathbf{2 1}$ in the case of $(E)$ pyrrole and indole substituted ethylene and (Z)-isomer, respectively (Scheme 16).

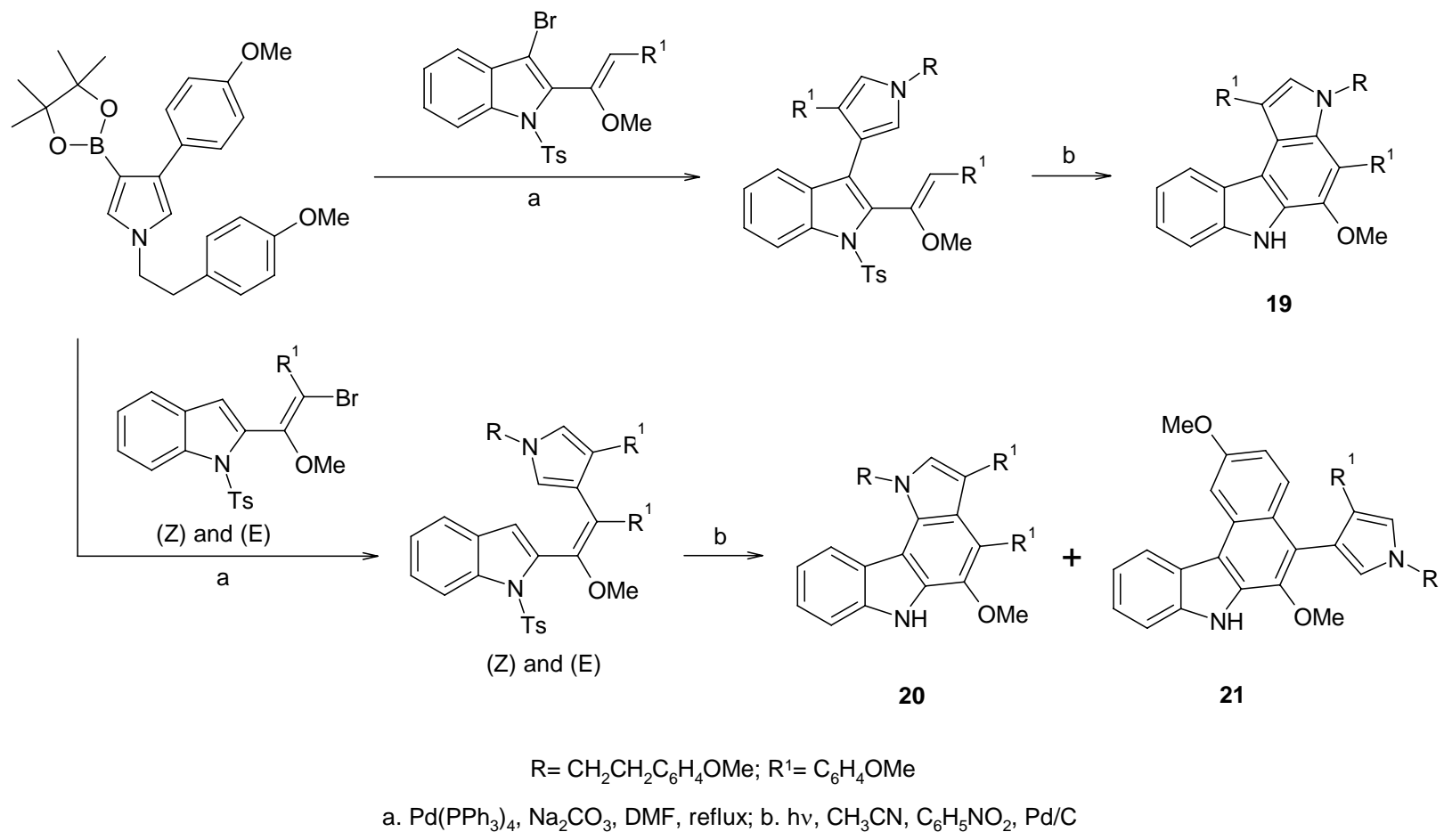

\section{Scheme 16}

2.1.4 Syntheses of helical scaffolds containing one or more $\mathbf{N}-\mathbf{N}$ bonds. For the synthesis of 7,8-diaza[5]helicene 22, a compound first obtained in the early $20^{\text {th }}$ century, ${ }^{19}$ a very simple method was put forward, based on the oxidation of 2,2'-diamino-1,1'-binaphthyl with $\mathrm{m}$ chloroperoxybenzoic acid (MCPBA) (Scheme 17). Although the corresponding $N$-oxide and $N, N$ '-dioxide are obtained along with the desired product, they can be reduced in good yields using $\mathrm{LiAlH}_{4}{ }^{20}$ 
<smiles>Nc1ccc2ccccc2c1-c1c(N)ccc2ccccc12</smiles>

\section{Scheme 17}

Benin and coworkers $^{21}$ obtained the tricyclic helical 1,10-diheterosubstituted benzo[c]cinnoline 23 using a sequence of minimum 5 reactions, while also investigating alternate synthetic routes. The key intermediate, 2-amino-2',6-dinitro-6'-propylthiobiphenyl, was obtained via an Ullmann coupling followed by a selective reduction of one nitro group. The helical benzo[c]cinnoline $\mathbf{2 3}$ was obtained by reducing the two nitro groups with Raney Ni and cleaving the amino protecting group (Scheme 18). The helicity of this compound was evidenced using X-ray analysis.
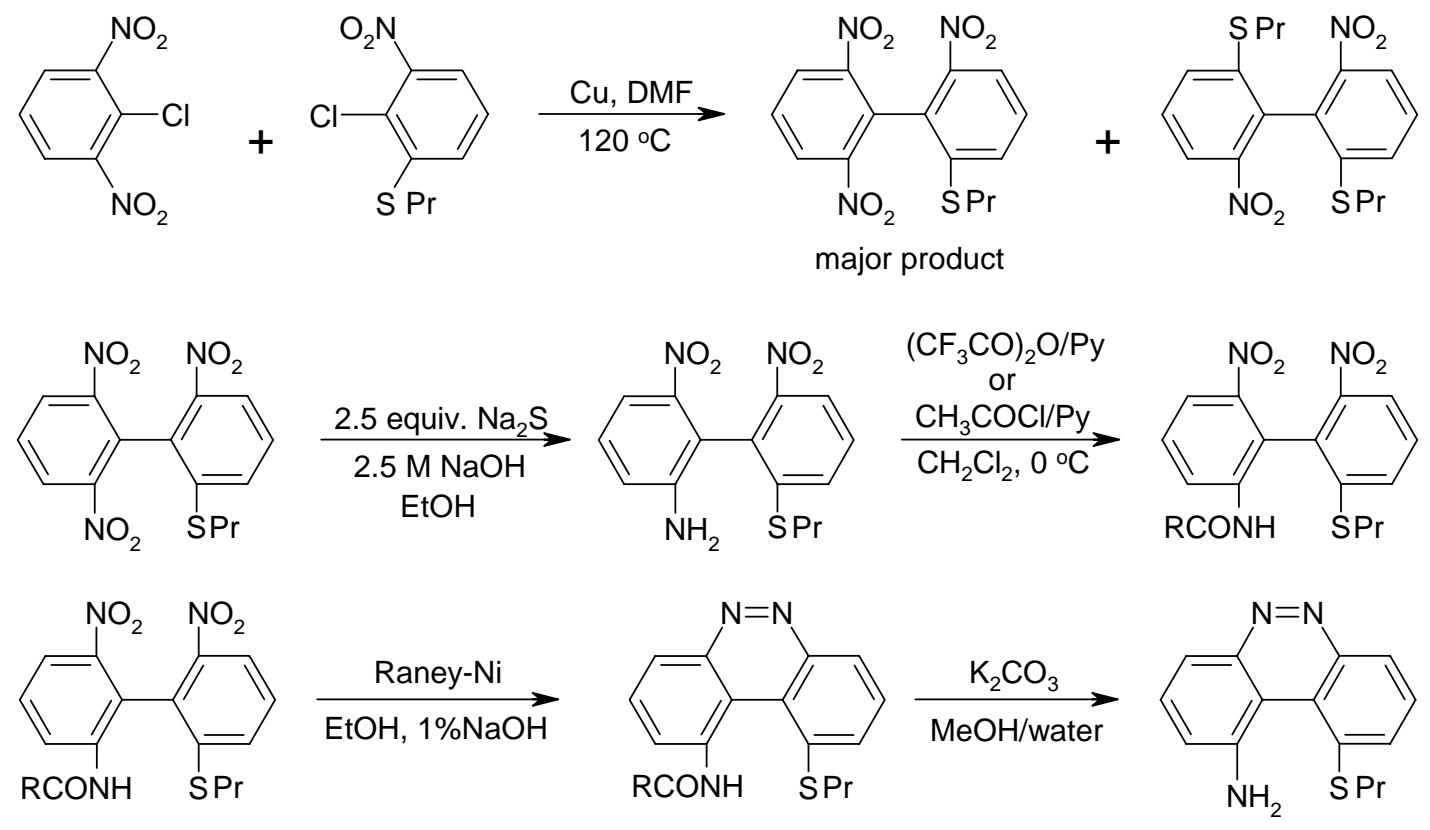

23

\section{Scheme 18}

While investigating various synthetic methods for $N, N^{\prime}$-dioxides, Rajca ${ }^{22}$ obtained the conjoined double azahelicene 24 . This chemical transformation was conducted in good yields via three homocouplings (a C-C and two N-N) between two molecules of diamine 25 in the presence 
of a twofold excess of benzoyl peroxide (Scheme 19). The stereostructure of compound 24 was determined using X-ray diffraction. Its racemization barrier was estimated to be higher than that of parent [5]helicene using NMR spectroscopy.<smiles>CC(C)(C)c1ccc2c(c1)C(C)(C)c1cc3c(cc1N2)Nc1ccc(C(C)(C)C)cc1C3(C)C</smiles>

25

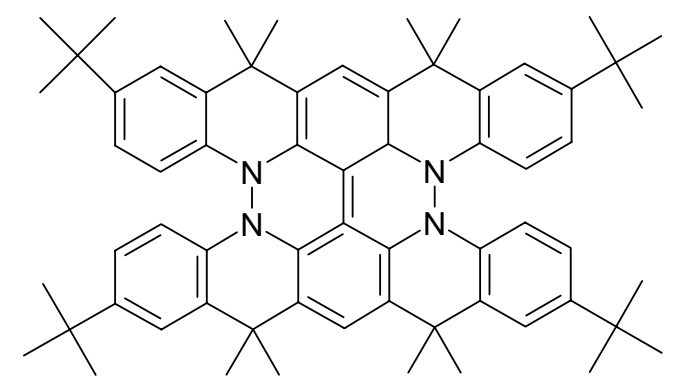

24

\section{Scheme 19}

2.1.5 $[2+2+2]$ Trimerization reactions. Stary et al. $^{23}$ recently applied a $[2+2+2]$ cobalt catalyzed trimerization strategy for obtaining 1,14-diaza[5]helicene and 1- and 2-aza[6]helicene. The key precursors for the [2+2+2] cyclotrimerization, aromatic triynes $\mathbf{2 6}$ were obtained from the corresponding bromopyridines upon treatment with lithiated 1-(triisopropylsilyl)-1-propyne and subsequent Sonogashira coupling. The $\left[\mathrm{CpCo}(\mathrm{CO})_{2}\right]$ catalyzed trimerization resulted in the formation of tetrahydro derivatives, which were aromatized to 27 and $\mathbf{2 8}$ in the presence of $\mathrm{MnO}_{2}$ (Scheme 20). The fully aromatic 1- and 2-aza[6]helicenes enantiomers were separated using HPLC with chiral stationary phases and their absolute configurations were investigated using CD spectroscopy. Their helicity degree was ascertained by X-ray analysis of the corresponding Ag complexes. Recently, the authors used this approach to obtain a number of new penta and hexacyclic azahelicenes. ${ }^{24}$ 


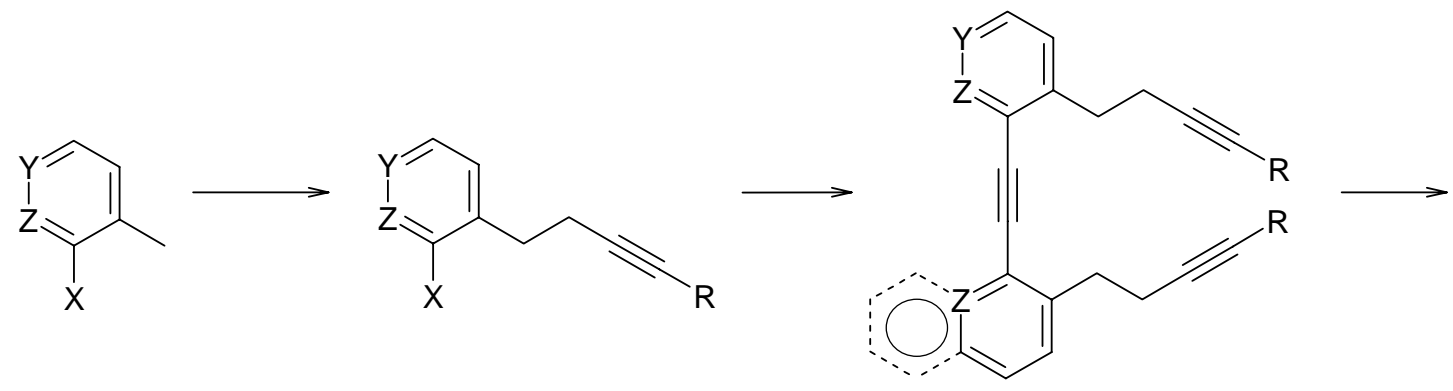

26

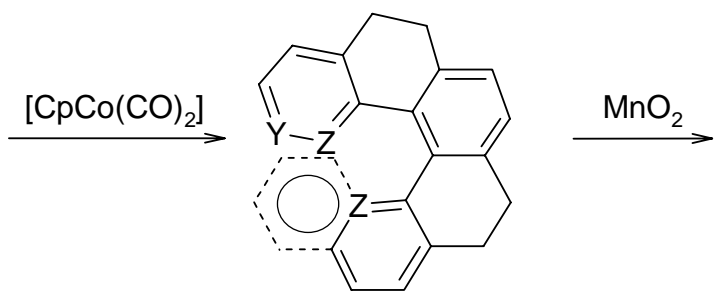<smiles>c1cnc2c(c1)ccc1ccc3ccc4cccnc4c3c12</smiles>

27

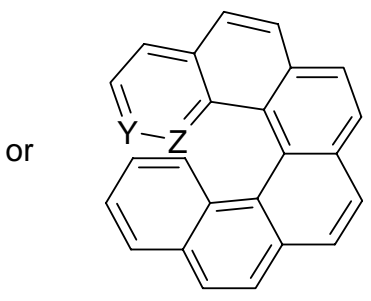

28

$\mathrm{Z}=\mathrm{N}, \mathrm{Y}=\mathrm{CH} ; \mathrm{Z}=\mathrm{CH}, \mathrm{Y}=\mathrm{N}$

\section{Scheme 20}

2.1.6 Sulfination of bisindole derivatives. The treatment of 3,3'-bisindolyl derivatives with elemental sulfur in DMF at reflux resulted in the formation of helical diaza tetrasulfides 29 in $59 \%$ yield and 19\% yield for the dimethyl derivative, respectively (Scheme 21). The helical nature of compounds 29 in solid state was ascertained using X-ray diffraction methods. ${ }^{25}$<smiles>[R]n1cc(-c2cn([R])c3ccccc23)c2ccccc21</smiles>
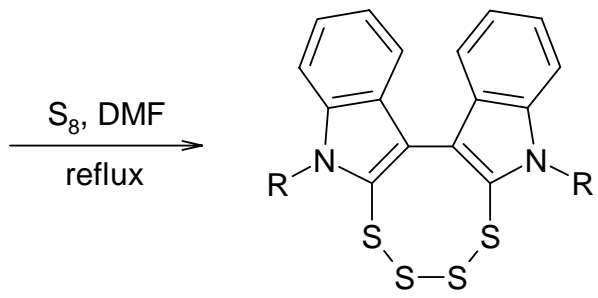

$\mathrm{R}=\mathrm{H}, \mathrm{CH}_{3}$

29

\section{Scheme 21}

\subsubsection{Consecutive Knoevenagel condensation/Diels-Alder cycloadditions. Dipyrazolo} tetracyclic derivatives $\mathbf{3 0}$ were constructed via a domino Knoevenagel condensation/ intramolecular hetero Diels-Alder cycloaddition (Scheme 22). The reaction was found to be completely diastereoselective and the yields to decrease upon increasing the bulkiness of the 
pyrazole substituents. X-ray analysis showed a strong distortion of the tetracyclic system, the angle between the pyrazolic rings falling in the range of 60-80 degrees. ${ }^{26}$<smiles>[R]c1nn(-c2ccccc2)c(Cl)c1C=O</smiles><smiles>[BH2-][CH]</smiles><smiles>[R]c1nn(-c2ccccc2)c(SCC=C(C)C)c1C=O</smiles><smiles>[R]C1=NN(c2ccccc2)C(=O)/C1=C\c1c([R])nn(-c2ccccc2)c1SCC=C(C)C</smiles>

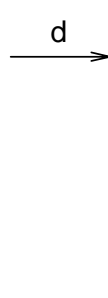

$\mathrm{d} \longrightarrow$<smiles>[R]c1nn(-c2ccccc2)c2c1[C@H]1c3c(nn(C)c3O[C@H]2CC)CC1(C)C</smiles>

30

a. 4-bromo-2-methyl-2-butene, thiourea, EtOH, reflux; b. $\mathrm{NaOH}, \mathrm{EtOH}$, reflux;

c. pyrazolone derivatives, EDDA, $\mathrm{CH}_{3} \mathrm{CN}$, rt; d. reflux.

\section{Scheme 22}

\subsection{Side annulation or substituent insertion}

2.2.1 Oxidation reactions. Phenanthro-2-yl or benzo[ $h]$ quinol-2-yl pyrilium salts were obtained by treating the corresponding 2-amino derivatives with 2,4,6-triphenyl-pyrylium perchlorate. The ferricyanide oxidation of such salts led to the formation of the tetracyclic imidazo[1,2a][1,10]phenanthrolines 31 along with compounds 32 in various ratios (Scheme 23). The helical structure of derivatives $\mathbf{3 1}$ was deduced using semi-empirical molecular computations. However, the mechanism of the ferricyanide oxidation process is not yet fully understood and requires further investigation. 
<smiles>[R]c1cc(N)nc2c1ccc1ccccc12</smiles>

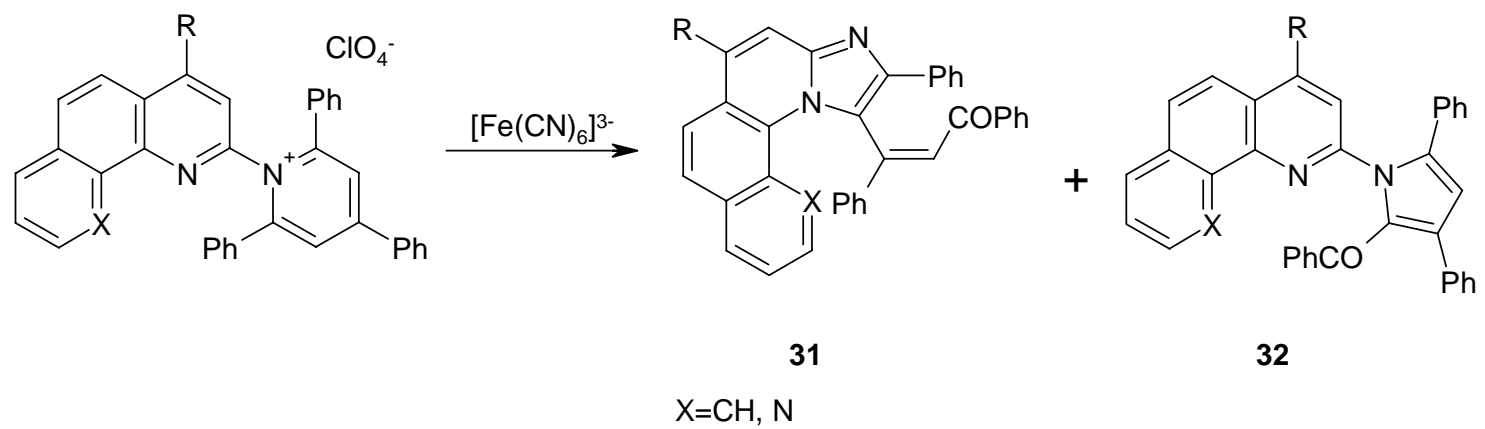

\section{Scheme 23}

Compounds 33, 34, 35 and 36 were obtained while investigating the reaction between 6,8dimethylpyrimido[4,5-c]pyridazine-5,7(6H,8H)-diones and cyclooctylamine or cycloheptylamine, respectively, in the presence of $\mathrm{AgPy}_{2} \mathrm{MnO}_{4}$ as oxidant (Scheme 24). ${ }^{28,29}$ Although no data on the helicity of these compounds was presented, comparison with other literature examples suggests a possible helical distortion.
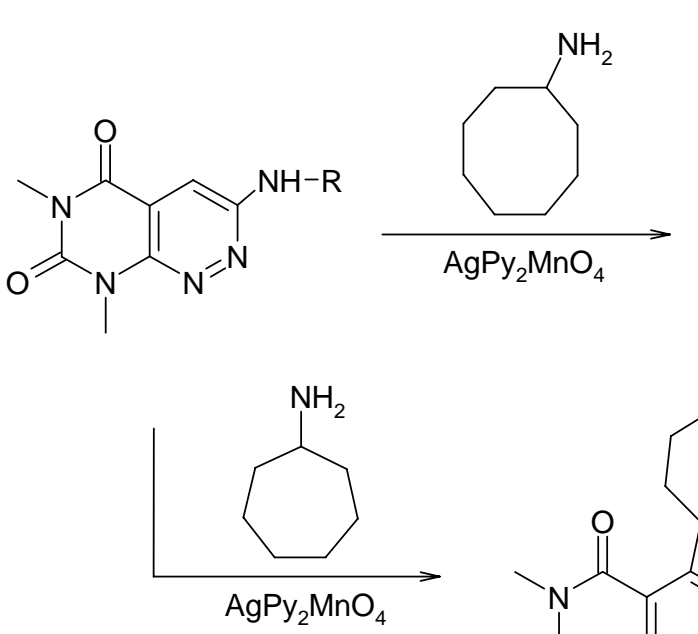<smiles></smiles>

33<smiles>[R]n1c2c(c3c4c(=O)n(C)c(=O)n(C)c4nnc31)CCC2</smiles>

34<smiles></smiles>

35<smiles></smiles>

36

Scheme 24 
Rozen and Dayan ${ }^{30}$ obtained $N, N$ '-phenanthrolinium dioxide $\mathbf{3 7}$ for the first time by treating 1,10-phenanthroline with fluorine in aqueous acetonitrile, the unstable compound $\mathrm{HOF}^{\cdot} \mathrm{CH}_{3} \mathrm{CN}$ being the active oxygen donor (Scheme 25). The synthesis of this dioxide using other oxidizing reagents was unsuccessful. The torsion angle between the nitrogen atoms in the bay region, as measured by X-ray diffraction techniques, has a very high value of over 30 degrees.

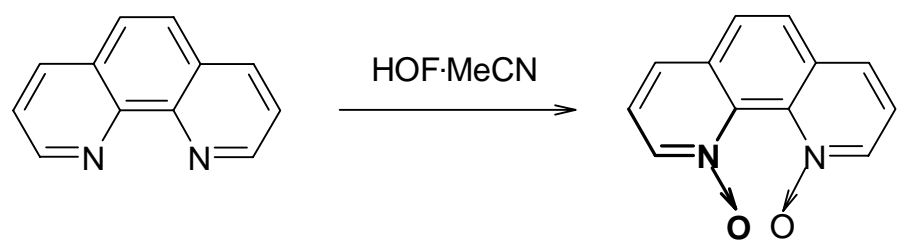

37

\section{Scheme 25}

2.2.2 N-ylide 1,3-dipolar cycloadditions. The key intermediates for helical pyrrolophenanthrolines 38, 1,10-phenanthrolinium salts 39 were obtained from 1,10phenanthroline and 2-bromoacetophenones. In methanol at $0{ }^{\circ} \mathrm{C}$ in the presence of triethylamine and acetylenic dicarboxylates, the salts are deprotonated and the resulting $N$-ylides react with the acetylenic dipolarophile, furnishing the primary cycloadducts 40. In the presence of triethylamine at room temperature, cycloadducts $\mathbf{4 0}$ undergo a rearrangement resulting in secondary cycloadducts $\mathbf{4 1}$. Upon refluxing in ethanol, fully aromatic pyrrolophenanthrolines $\mathbf{3 8}$ are obtained. Another method implies the direct transformation of phenanthrolinium salts $\mathbf{3 9}$ to helical pyrrolophenanthrolines $\mathbf{3 8}$ via a one-pot reaction with olefinic dipolarophiles, triethylamine and tetrakispyridino cobalt(II) dichromate as the oxidant (Scheme 26).

Both salts 39 and pyrrolophenanthrolines $\mathbf{3 8}$ show helical distortion in solid state, as evidenced by X-ray analysis. The later also exhibits helicity in solution, as evidenced by NMR spectroscopy. ${ }^{31-40}$

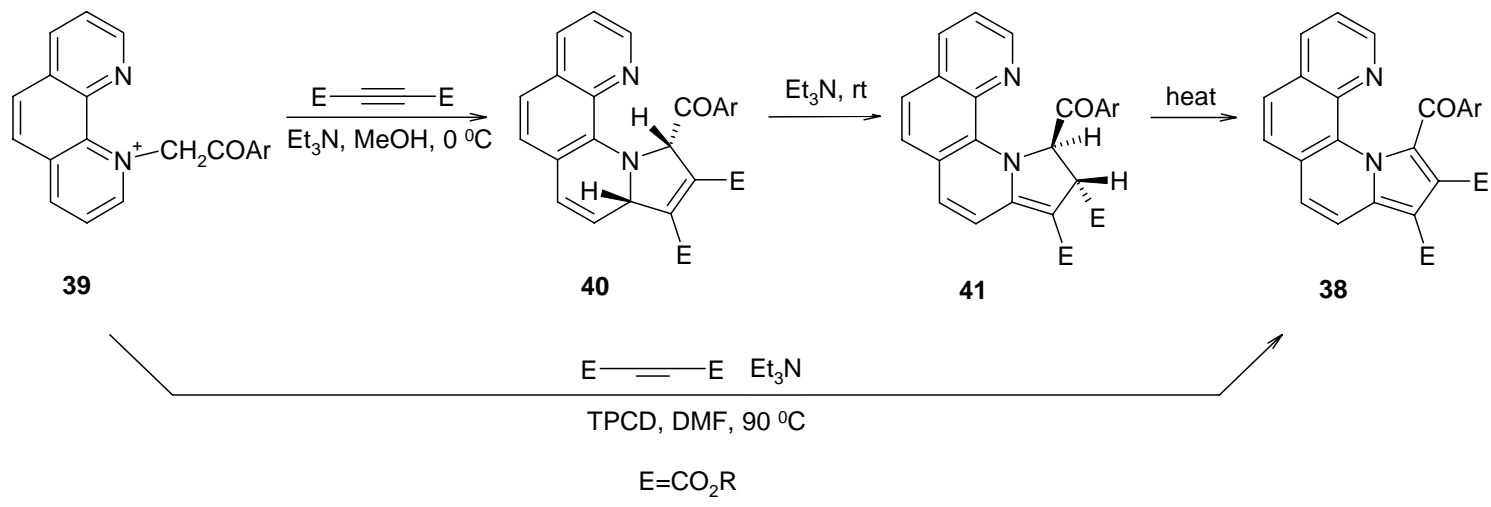

Scheme 26 
When applying the same one-pot approach as mentioned above to 4,5-diazafluoren-9-onium salts 42, pyrrolodiazafluorenones 43 were obtained in moderate yields (Scheme 27). Again, both salts and target compounds show helical distortion, even though it is significantly reduced by the presence of a smaller central five membered ring instead of the benzene ring in pyrrolophenanthrolines $38 .^{41-43}$<smiles>O=C(Cl)C[n+]1cccc2c1-c1ncccc1C2=O</smiles>

42

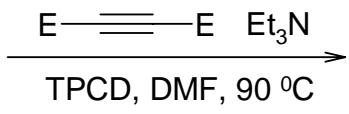<smiles>COC(=O)c1c(F)c(F)c2ccc3c(n12)-c1ncccc1C3=O</smiles>

43

$$
\mathrm{E}=\mathrm{CO}_{2} \text { Alk }
$$

\section{Scheme 27}

2.2.3 The reactions of acetylenic esters with tricyclic azines. A very convenient method for obtaining pentacyclic dipyrrolo compounds consists in treating phenanthroline derivatives with symmetrical acetylenic esters in methanol. The reaction yields the target dipyrrolo pentahelicenes in moderate yields. ${ }^{44}$ Recently, Maghsoodlou et al. ${ }^{45}$ applied this reaction to pyrazino[2,3-f][1,10]phenanthroline and dipyrido[3,2-a:2',3'-c]phenazine, obtaining dipyrrolo pentahelicenes 44 (Scheme 28).
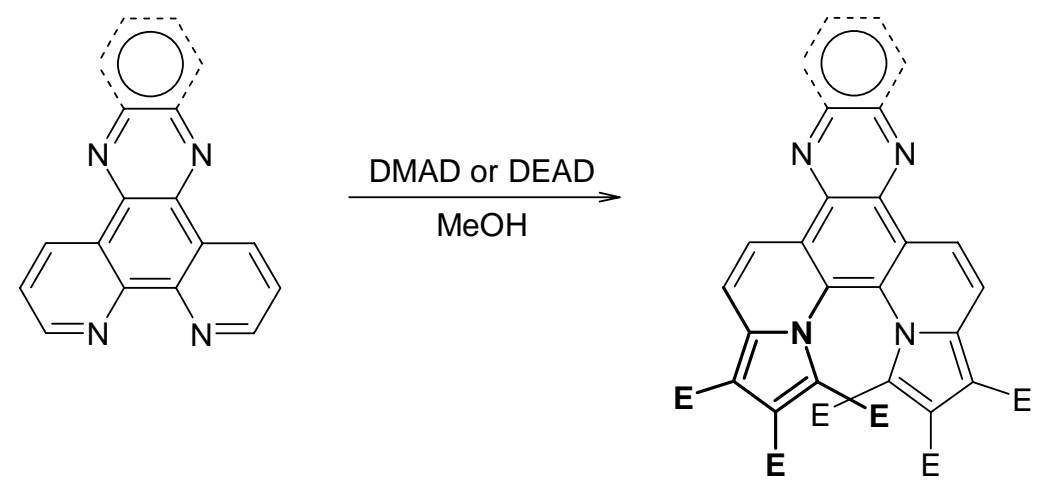

$\mathrm{E}=\mathrm{CO}_{2} \mathrm{Me}$ or $\mathrm{CO}_{2} \mathrm{Et}$

\section{Scheme 28}


When applying the same reaction to 2,9-dimethyl-[1,10]phenanthroline, formation of the unexpected cyclobuta[4,5]pyrrolo[1,2-a][1,10]phenanthroline system 45 was observed instead of the normal dipyrrolo derivative (Scheme 29). The helical nature of this compound was ascertained using X-ray analysis. ${ }^{46}$

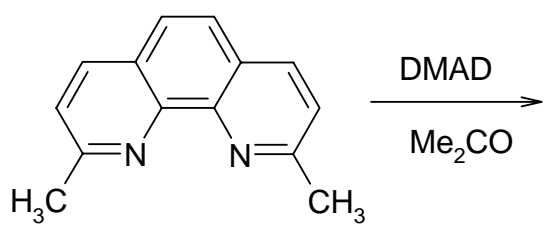

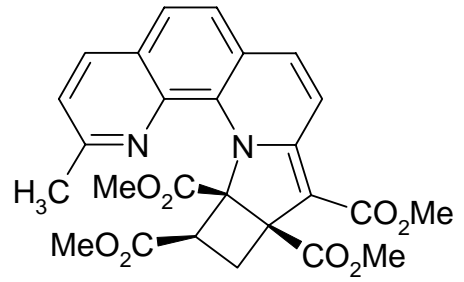

45

\section{Scheme 29}

2.2.4 Helical molecules built from $p$-substituted benzene. While attempting to synthesize linear diazonia pentacene derivatives as DNA intercalators, Ihmels et al. ${ }^{47}$ obtained the helical pentaphene derivatives 46 and 47. The formation of these unexpected compounds through a $N$ quaternization and a twofold acid-catalyzed cyclodehydration could be explained by a WagnerMeerwein migration of a methyl group (Scheme 30). Although these compounds contain only three ortho condensed rings substituted with a single methyl group, they were found to possess helical distortion in solid state.

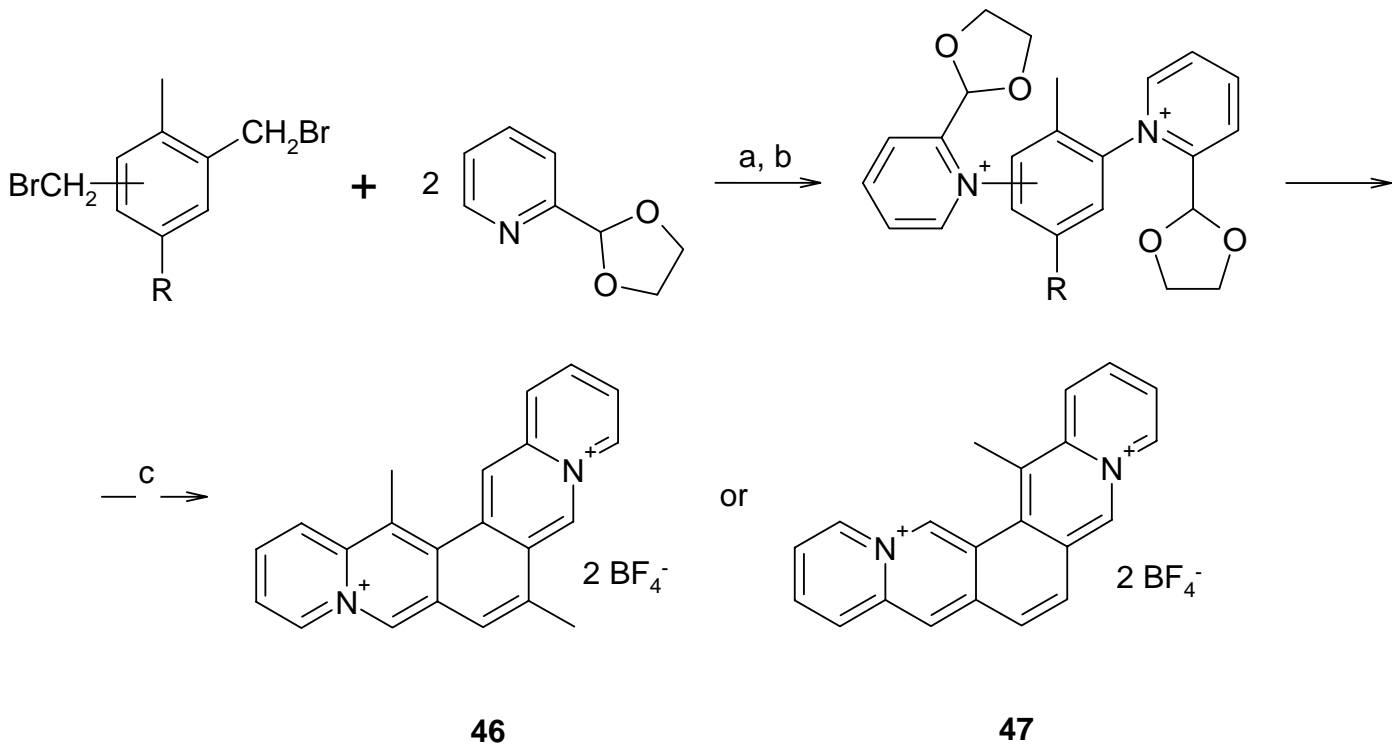

a. $\mathrm{N}$-methyl-2-pyrrolidone, r.t., 7 days; b. aq. $\mathrm{NaBF}_{4}$; c. polyphosphoric acid, $150{ }^{\circ} \mathrm{C}, 24 \mathrm{~h}$.

\section{Scheme 30}


Using the same reaction sequence on 1,7-bis(bromomethyl)naphthalene, the helical diazonia compound 48 was obtained as the major product, along with its planar isomer, 49 (Scheme 31). It is interesting to note that compared to the synthesis of derivatives $\mathbf{4 6}$ and $\mathbf{4 7}$, the absence of one or more methyl groups on the naphthalene ring system leads to a decrease in regioselectivity of the cyclodehydration reaction. ${ }^{48}$
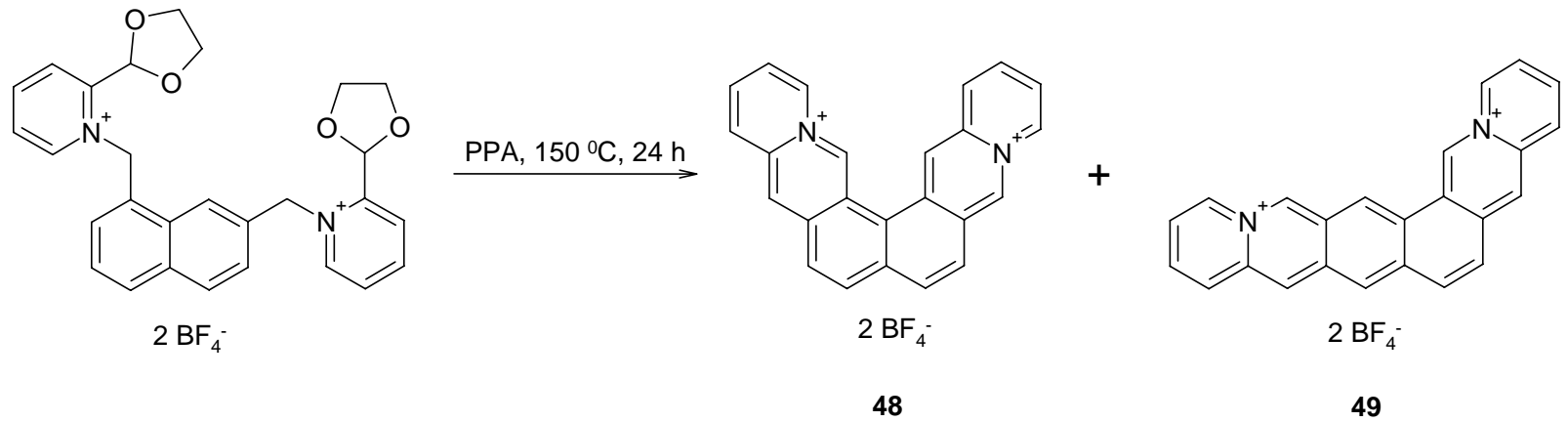

\section{Scheme 31}

Tanaka and coworkers ${ }^{49,50}$ developed a very simple approach for obtaining 13,14dialkyldibenzo $[b, j][4,7]$-phenanthrolines 50 starting from the readily available materials $N, N^{\prime}$ diphenyl- $p$-phenylenediamine and $n$-alkyl carboxylic acids. The double condensation reaction is completely regioselective and takes place in the presence of $\mathrm{ZnCl}_{2}$ as the Lewis acid under heating or, more efficiently, microwave irradiation. The selectivity of this reaction was explained by semi-empirical molecular computations. Compounds $\mathbf{5 0}$ were subjected to chiral HPLC separation and racemization studies. It was shown that the methyl derivative racemized relatively quickly at room temperature, while the ethyl derivative was more stable. Furthermore, the dihydro derivatives $\mathbf{5 1}$ obtained by treating the fully aromatic compounds $\mathbf{5 0}$ with $\mathrm{LiAlH}_{4}$ were more stable towards racemization (Scheme 32). The helical chirality of these compounds was determined by X-ray analysis and their absolute configuration by circular dichroism (CD) experiments. 


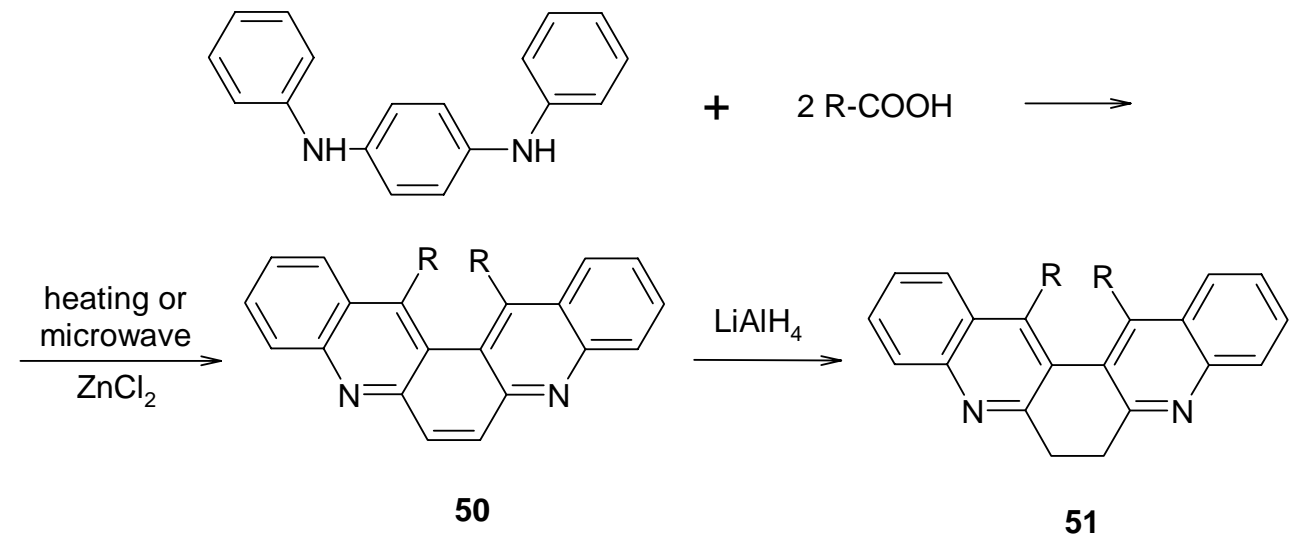

$\mathrm{R}=\mathrm{Me}, \mathrm{Et}$

\section{Scheme 32}

In order to obtain 6,9-, 5,10- and 2,13-diaza[5]helicenes 52, 53 and 54, Caronna and coworkers $^{51}$ applied a different synthetic pathway for each compound. Thus, 6,9diaza[5]helicene $\mathbf{5 2}$ was obtained by first reacting 1,4-diaminobenzene with 2chlorobenzaldehyde. The resulting diimine was cyclized using sodium amide. The aromatization to 52 was performed using $\mathrm{MnO}_{2}$ as oxidant agent (Scheme 33).
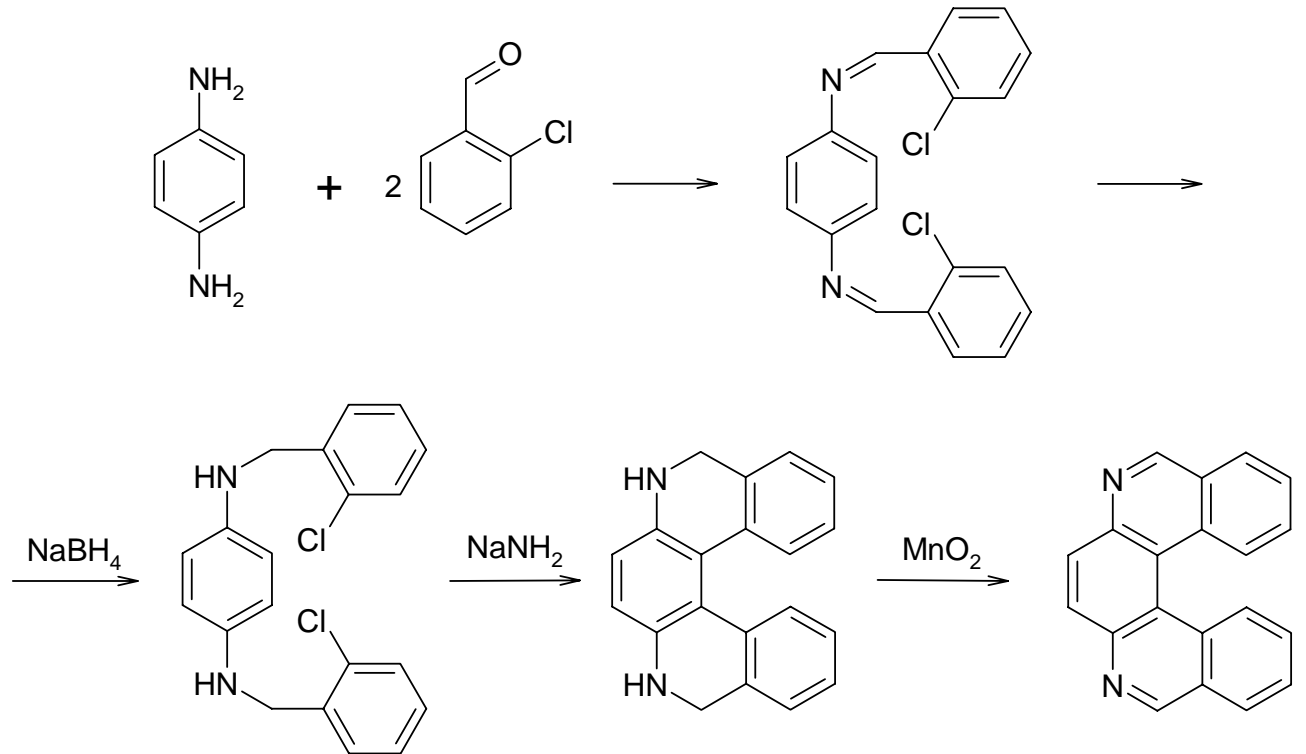

52

\section{Scheme 33}

In order to obtain 5,10-diaza[5]helicene 53, terephthalic aldehyde was reacted with aniline in a 1:2 ratio, and the resulting diimine was subjected to photocyclization in the presence of 
sulfuric acid. The photocyclization step was not fully regioselective, since isomer $\mathbf{5 5}$ was obtained along with helicene 53 (Scheme 34). ${ }^{51}$<smiles>O=Cc1ccc(C=O)cc1</smiles>

$+2$<smiles>NC(=O)c1ccccc1</smiles><smiles>C(=N\c1ccccc1)\c1ccc(/C=N/c2ccccc2)cc1</smiles>

$$
\underset{\mathrm{H}_{2} \mathrm{SO}_{4}}{\stackrel{\mathrm{hv}}{\longrightarrow}}
$$<smiles>c1ccc2c(c1)ncc1ccc3ncccc3c12</smiles>

53<smiles>c1ccc2c(c1)ccc1cc3c(cnc4ccccc43)cc12</smiles>

55

\section{Scheme 34}

The synthesis of 2,13-diazapentahelicene 54 was conducted using the ozonolysis of pyrene, followed by formation of the corresponding dialdehyde and ring closure in the presence of $\mathrm{P}_{2} \mathrm{O}_{5}$ and sulfuric acid (Scheme 35). ${ }^{51}$<smiles>COCC(CN)OC</smiles><smiles></smiles><smiles>C1CC2CC1CN2</smiles><smiles>O=Cc1cccc2ccc3cccc(C=O)c3c12</smiles><smiles>COC(CN=Cc1cccc2cccc(C=NCC(OC)OC)c12)OC</smiles><smiles>CCCC</smiles><smiles>c1cc2ccc3ccc4ccc5ccncc5c4c3c2cn1</smiles>

\section{Scheme 35}


2.2.5 Helical molecules built from 1,2,3-trisubstituted benzene. The reaction between 1bromo-2,6-di(carbomethoxy)-4-t-butyl benzene with diphenyl, 1-naphthylphenyl or 1,1'dinaphthyl amines in the presence of $\mathrm{Cu}$ resulted in triarylamines 56. Upon hydrolysis followed by treatment with oxalyl chloride and subsequent Friedel-Crafts acylation/cyclization in the presence of $\mathrm{SnCl}_{4}$, compounds 57, 58 and 59 were obtained in good yields (Scheme 36). The use of other Lewis acids such as $\mathrm{FeCl}_{3}$ for the acylation step led to a decrease in the regioselectivity of the cyclization. The helical distortion in compounds 57, 58 and 59, as determined by X-ray diffraction methods, increases progressively from 43 to 60 degrees. ${ }^{52}$

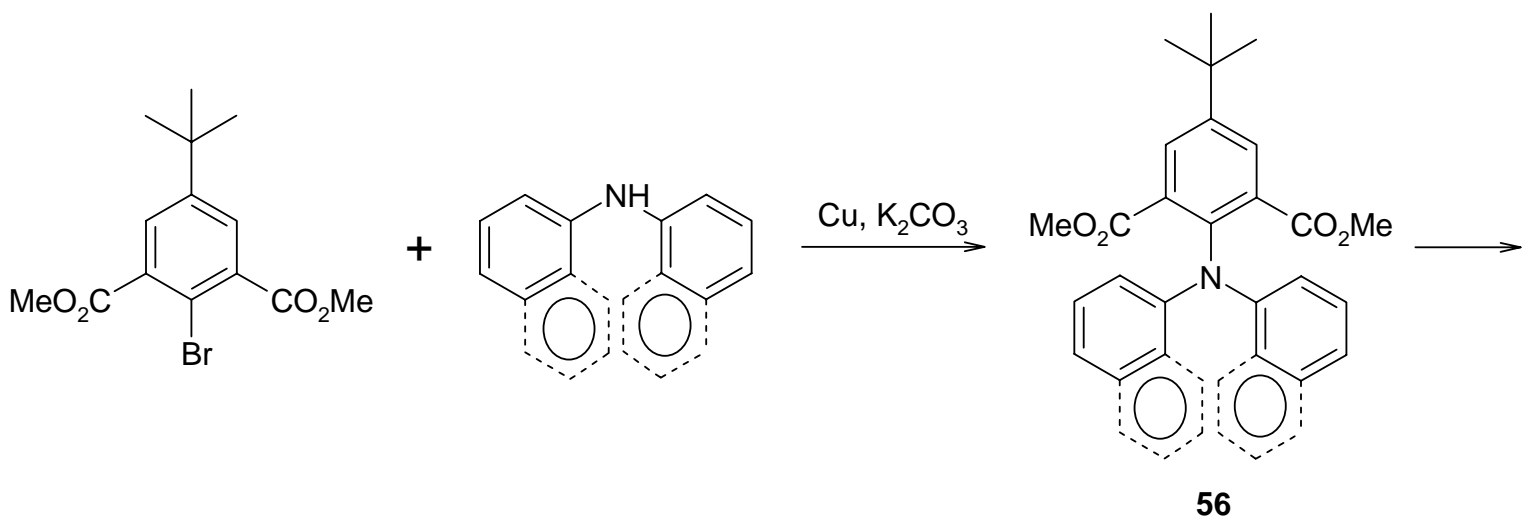<smiles></smiles>

\section{Scheme 36}

In their search for novel cationic dyes, Laursen and coworkers ${ }^{53,54}$ obtained a number of helical dimethoxyquinacridinium derivatives. The synthetic pathway implies the reaction of stable carbocation 60 with aliphatic amines in the presence of $N$-methylpyrrolidone. In order to separate their enantiomeric counterparts, dimethoxyquinacridiniums $\mathbf{6 1}$ were treated with either acetonitrile and sodium hydride, or with $(+)-(R)$-methyl- $p$-tolylsulfoxide. The resulting diastereoisomers were separated by column chromatography. Upon treatment with $\mathrm{HPF}_{6}$ in acetone, the dimethoxyquinacridinium derivatives 61 were regenerated (Scheme 37). 
These compounds were studied extensively by circular dichroism and X-ray diffraction methods, showing a significant degree of helicity. Furthermore, this helical conformation proved to be more thermodynamically stable than that of famous [6]helicene. ${ }^{55-57}$

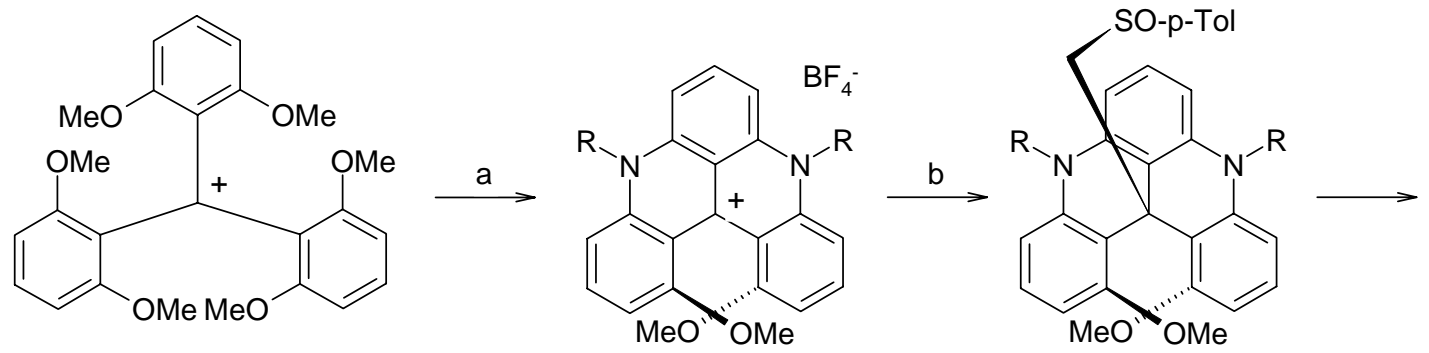

60

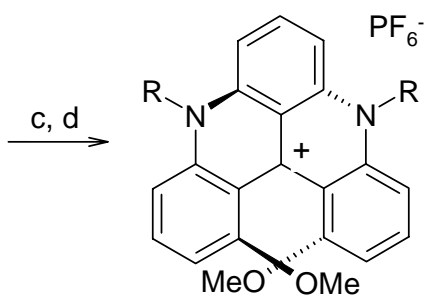

$(P)-61$<smiles>[R]N1Cc2cccc3c2[C@@H](c2c(OC)cccc21)c1c(OC)cccc1N3[R]</smiles>

(M)-61

a. $\mathrm{RNH}_{2}$, N-methylpyrrolidone (NMP), $1.5 \mathrm{~h}, 110^{\circ} \mathrm{C}$; b. (+)-(R)-methyl-p-tolylsulfoxide, LDA, THF, $0{ }^{\circ} \mathrm{C}$; c. column chromatography (SiO2); d. aq HPF6, acetone

\section{Scheme 37}

2.2.6 Diels-Alder cycloaddition reactions. Using a previously developed method for obtaining carbohelicenes, Dreher and Katz ${ }^{59}$ synthesized symmetrical pentaazahelicenes 62 in multigram quantities. $^{58}$ The approach consists of a simple three step procedure, starting from 3,6diacetylated carbazole derivatives. These were transformed into their corresponding enolates upon treatment with triisopropylsilyl triflate (TIPSOTf). The enolates were reacted with 1,4benzoquinone, resulting in the target compounds 62, together with considerable amounts of isomeric 63 and traces of 64 (Scheme 38). Separation of 62 and 63 takes place readily, since the target helicenes are not soluble in pentanes, while their isomers are.

The absolute configuration of derivatives $\mathbf{6 2}$ was ascertained by treatment with $S$ )-(-)camphanoyl chloride, followed by chromatographic separation of the corresponding diastereoisomers and subsequent CD spectroscopy. 


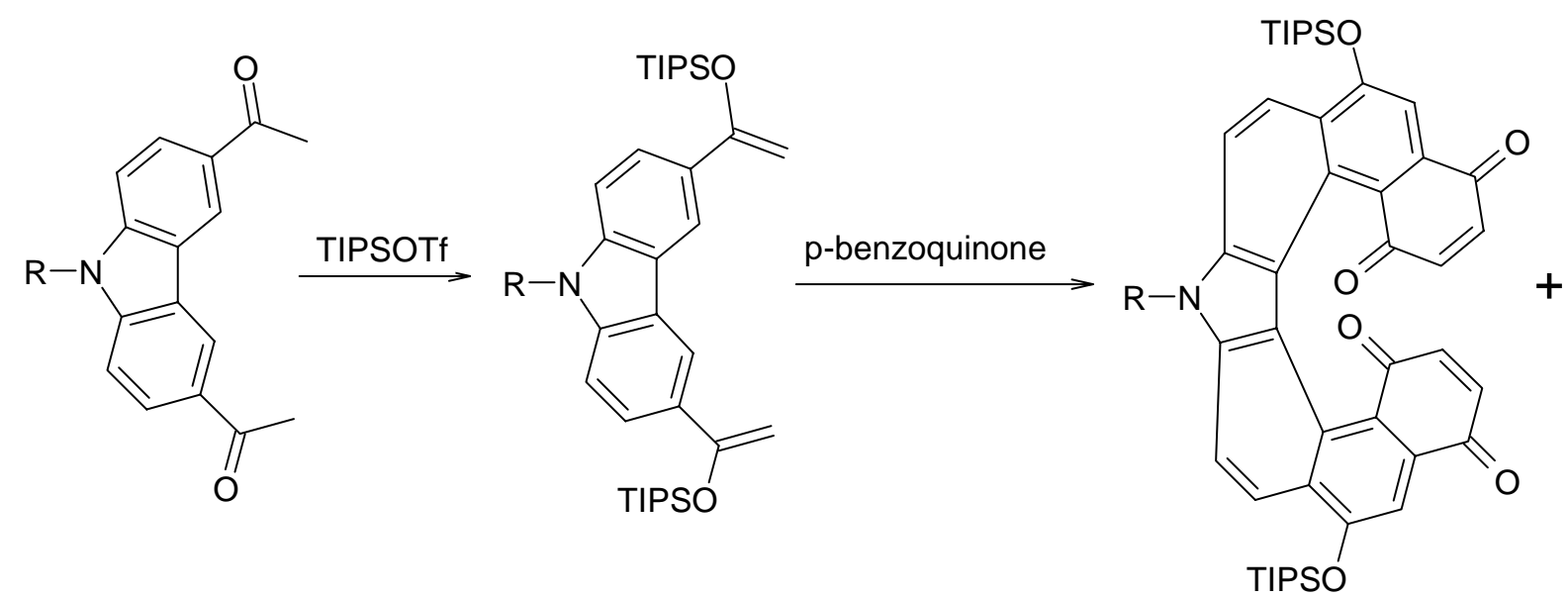

62<smiles></smiles>

63<smiles>[R]n1c2cc3c(cc2c2cc4c(O[AsH2])cc5c(c4cc21)C(=O)C=CC5=O)C(O[AsH3])C=CC3=O</smiles>

64

$\mathrm{R}=\mathrm{Me}, \mathrm{n}-\mathrm{C} 12 \mathrm{H} 25$

\section{Scheme 38}

2.2.7 Synthesis of expanded helicenes. By using a series of condensation reactions, Bell and Jousselin $^{60}$ obtained the expanded azahelicenes 65 and 66 in six and seven consecutive steps, respectively (Scheme 39). Purification of these compounds revealed that both expanded azahelicenes form 1:1 complexes with $\mathrm{Na}^{+}$ions. H-NMR studies indicated that although both the free compounds and their corresponding sodium complexes are prone to relatively fast racemization, the inclusion of the $\mathrm{Na}^{+}$ion in the molecular coil stabilizes the helical conformation to a small degree. 


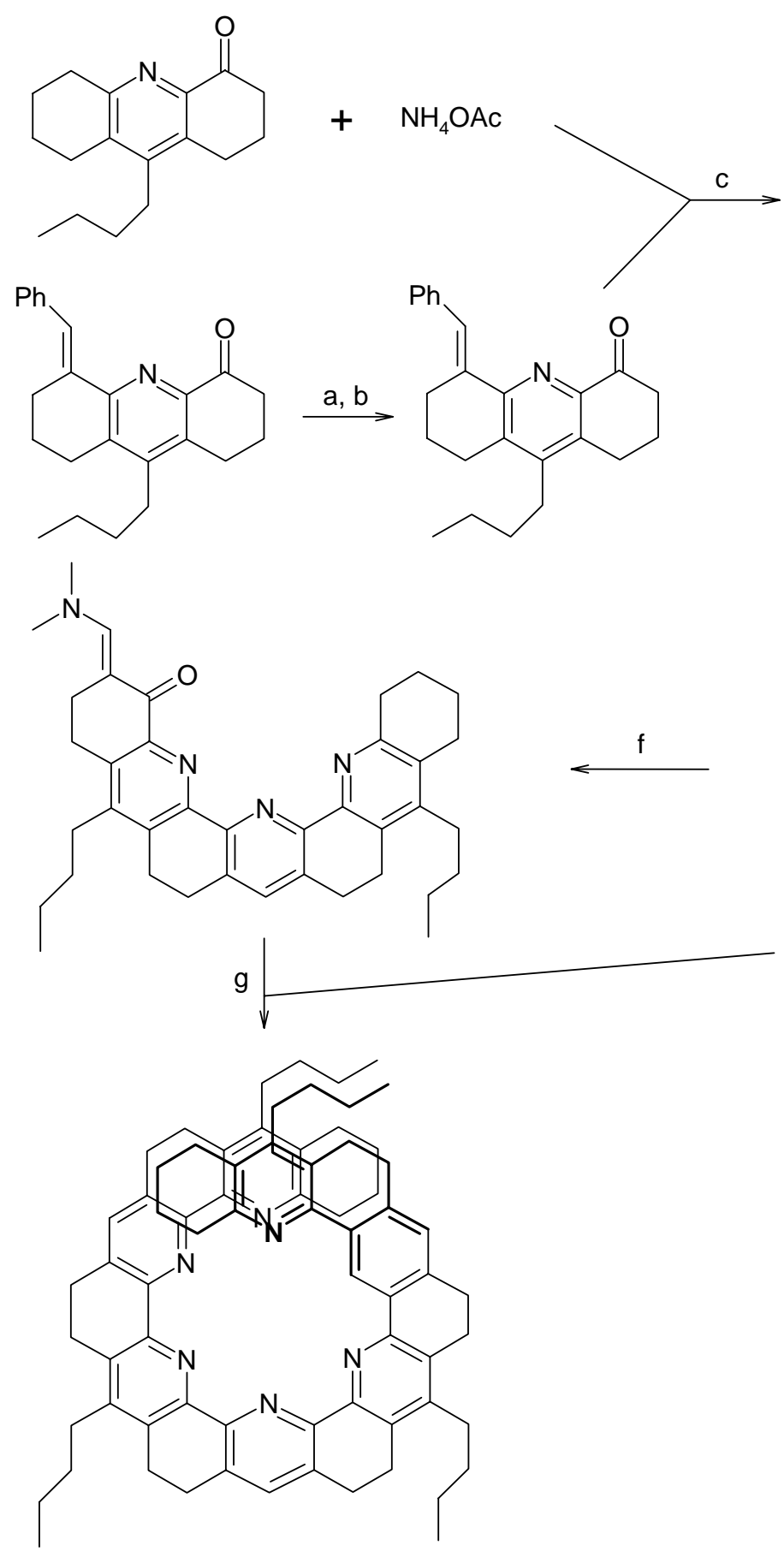

65<smiles></smiles><smiles>CCCCc1c2c(nc3c1CCc1cc4c(nc1-3)-c1nc3c(c(CCCC)c1CC4)CCCC3=O)CCCC2</smiles>

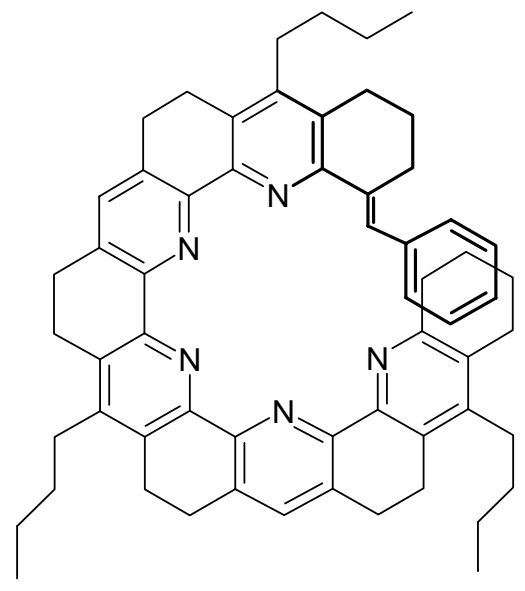

66

a. $\mathrm{Me}_{2} \mathrm{NCH}_{2} \mathrm{Cl}, \mathrm{CH}_{3} \mathrm{CN}$; b. $\mathrm{NaOH}, \mathrm{H}_{2} \mathrm{O}, \mathrm{CH}_{2} \mathrm{Cl}_{2} / \mathrm{CH}_{3} / / \mathrm{Et}_{3} \mathrm{~N}, \mathrm{CH}_{2} \mathrm{Cl}_{2}$; c. DMSO; d. $\mathrm{O}_{3}, \mathrm{CH}_{2} \mathrm{Cl}_{2}, \mathrm{CH}_{3} \mathrm{OH} / \mathrm{Me}_{2} \mathrm{~S}$; e. $\mathrm{NH}_{4} \mathrm{OAC}, \mathrm{DMSO}, 95^{\circ} \mathrm{C}$; f. $t$-BuOCH$\left(\mathrm{NMe}_{2}\right)_{2}, 80^{\circ} \mathrm{C}$; g. $\mathrm{NH}_{4} \mathrm{BF}{ }_{4}, \mathrm{DMF}, 150^{\circ} \mathrm{C}$.

\section{Scheme 39}




\section{Properties}

The helical nature of the above mentioned molecules was ascertained usually in solid state by Xray single crystal analysis. However, there are also a few examples of NMR studies on the helicity of such compounds. . $^{37,43,60}$

To our knowledge, no fully enantiomerically selective synthesis was reported to date, even though some synthetic methods offer a moderate enantiomeric excess. ${ }^{11}$ Enantiomeric separation was performed using either chiral column chromatography or a chiral complexation agent (for example TAPA), followed by standard chromatographic separation.

The racemization times and absolute configurations were determined using CD spectroscopy. Although an increase in the number of ortho annulated rings generally leads to an increase in the racemization time and conformational stability, some tetracyclic compounds exhibit an unusually high thermal conformational stability. ${ }^{52,55-57}$

A comprehensive study of the circular dichroism properties of monoaza[5]helicenes was conducted by Caronna et al. ${ }^{61,62}$ It was observed that although the studied compounds showed similar features to the parent [5] helicene, all of them had shorter racemization time and showed distinct features due to the presence of the nitrogen atom.

Ihmels and coworkers ${ }^{63}$ showed that diazonia derivatives $\mathbf{4 6}, \mathbf{4 7}$ and 48 have a high binding selectivity for triple-helical DNA, most probably due to their double charge and helical molecular shape. To the best of our knowledge, such compounds are the only known examples of polycyclic aromatics acting as DNA intercalators without a functionalized side-chain attached to the ring system.

The proton affinities of 1- and 2-aza[6]helicene were measured using MS techniques and calculated using density functional molecular computations. The energies observed were comparable to those of classical "proton sponges", recommending the tested compounds as chiral superbases. ${ }^{64}$

Pyrrolophenanthrolines 38 were tested for thin film conductivity with good results, suggesting a possible use for nitrogen bearing helical aromatics in the field of optoelectronics. ${ }^{65}$

\section{References}

1. (a) Wynberg, H. Acc. Chem. Res. 1971, 4, 65. (b) Groen, M. B.; Schandenberg, H., Wynberg, H. J. Org. Chem. 1971, 36, 2797. (c) Groen, M. B., Wynberg, H. J. Am. Chem. Soc. 1971, 93, 2968.

2. Sato, K.; Arai, S. Heterohelicenes Containing Nitrogen Aromatics: Azahelicenes and Azoniahelicenes In Cyclophane Chemistry for the 21st Century Takemura, H., Ed., Research Signpost: Kerena, India, 2002; pp 173 - 197.

3. (a) Martin, R. H. Angew. Chem. Int. Ed. 1974, 13, 649. (b) Laarhoven, W. H.; Prinsen, W. J. C., Topp. Curr. Chem. 1984, 125, 65. (c) Meurer, K. P.; Vogtle, F. Topp. Curr. Chem. 1985, 
127, 1. (d) Grimme, S.; Harren, J; Sobanski, A., Vogtle, F. Eur. J. Org. Chem. 1998, 1491. (e) Urbano, A.; Angew. Int. Chem. Ed. 2003, 42, 3986.

4. (a) Newman, M. S.; Luts, W. B.; Lednicer, D. J. Am. Chem. Soc. 1955, 77, 3420. (b) Newman, M. S.; Lednicer, D. J. Am. Chem. Soc. 1956, 78, 4765.

5. (a) Bazzini, C.; Brovelli, S; Caronna, T.; Gambarotti, C.; Giannone, M.; Macchi, P.; Meinardi, F.; Mele, A.; Panzeri, W.; Recupero, F.; Sironi, A.; Tubino, R. Eur. J. Org. Chem. 2005, 1247-1257. (b) Caronna, T.; Fontana, F.; Longhi, G.; Mele, A.; Sora, I. N.; Panzeri, W.; Viganò, L. Arkivoc, 2009, (viii), 145.

6. Abbate, S.; Bazzini, C.; Caronna, T.; Fontana, F.; Gambarotii, C.; Gangemi, F.; Longhi, G.; Mele, A.; Sora, I. N.; Panzeri, W. Tetrahedron 2006, 62, 139.

7. Aloui, F.; El Abed, R.; Ben Hassine, B. Tetrahedron Lett. 2008, 49, 1455.

8. Sato, K.; Katayama, Y.; Yamagishi, T.; Arai, S. J. Heterocyclic Chem. 2006, 43, 177.

9. Pakray, S.; Castle, R. N. J. Heterocyclic Chem. 1987, 24, 231.

10. Sasaki, K.; Castle, R. N. J. Heterocyclic Chem. 1992, 29, 963.

11. Osuga, H.; Suzuki, H.; Tanaka, K. Bull. Chem. Soc. Jpn., 1997, 70, 891.

12. Harrowven, D.C.; Guy, I. L.; Nanson, L., Angew. Chem. Int. Ed. 2006, 45, 2242.

13. Nakano, K.; Hidehira, Y.; Takahashi, K.; Hiyama, T.; Nozaki, K., Angew. Chem. Int. Ed. 2005, 44, 7136.

14. Sato, A.; Morishita, T.; Shiraki, T.; Yoshioka, S.; Horikoshi, H.; Kuwano, H.; Hanzawa, H.; Hata, T. J. Org. Chem. 1993, 58, 7632.

15. Warabi, K.; Matsunaga, S.; van Soest, R. W. M.; Fusetami, N. J. Org. Chem. 2003, 68, 2765.

16. Furstner, A.; Domostoj, M. M.; Scheiper, B. J. Am. Chem. Soc. 2005, 127 (33), 11620.

17. Furstner, A.; Domostoj, M. M.; Scheiper, B. J. Am. Chem. Soc. 2006, 128, 8087.

18. Ayats, C.; Soley, R.; Albericio, F.; Alvarez, M. Org. Biomol. Chem. 2009, 7, 860.

19. Meisenheimer, J.; Witte, K. Chem. Ber. 1903, 36, 4153.

20. Caronna, T.; Fontana, F.; Mele, A.; Sora, I. N.; Panzeri, W.; Vigano, L. Synthesis 2008, 413.

21. Benin, V.; Kaszynski, P.; Pink, M.; Young, V. G. Jr. J. Org. Chem. 2000, 65, 6388.

22. Shiraisi, K; Rajca, A.; Pink, M.; Rajca, S. J. Am. Chem. Soc. 2005, 127, 9312.

23. Misek, J.; Teply, F.; Stara, I. G.; Tichy, M.; Saman, D., Cisarova, I.; Vojtisek, P., Stary, I. Angew. Chem. Int. Ed. 2008, 47, 3188.

24. Andronova, A.; Szydlo, F.; Teply, F.; Tobrmanova, M.; Volot, A.; Stara, I. G.; Stary, I.; Rusilek, L.; Saman, D.; Cvacka, J.; Fiedler, P.; Vojtisek, P. Collect. Czech. Chem. Commun. 2009, 74, 189.

25. Janosik, T.; Bergman, J.; Stensland, B.; Stalhandske, C. J. Chem. Soc., Perkin Trans. 1 2002, 330.

26. Ceulemans, E.; Voets, M.; Emmers, E.; Uytterhoeven, K.; Van Mervelt, L.; Dehaen, W. Tetrahedron 2002, 58, 531.

27. Bohm, S; Strnad, T.; Ruppertove, I.; Kuthan, J. Collect. Czech. Chem. Commun. 1997, 62, 1599. 
28. Gulevskaya, A.; Serduke, O. V.; Pozharskii, A. F.; Besedin, D. V. Tetrahedron 2003, 59, 7669.

29. Serduke, O. V.; Gulevskaya, A.; Pozharskii, A. F.; Starikova, Z. A.; Profatilova, I. A. Tetrahedron 2006, 62, 652.

30. Rozen, S.; Dayan, S. Angew. Chem. Int. Ed. 1999, 38, 3472.

31. Dumitrascu, F.; Mitan, C. I.; Drăghici, C.; Căproiu, M. T.; Răileanu, D. Tetrahedron Lett. 2001, 42, 8379.

32. Dumitrascu, F.; Mitan, C. I.; Drăghici, C.; Căproiu, M. T. Rev. Roum. Chim. 2002, 47, 881; Chem. Abstr. 2004, 140, $111296 \mathrm{e}$.

33. Dumitrascu, F.; Mitan, C. I.; Drăghici, C.; Căproiu, M. T.; Răileanu, D. Rev. Chim. (Bucharest) 2002, 53, 787; Chem. Abstr. 2003, 138, 368790m.

34. Dumitrascu, F.; Caira, M. R.; Drăghici, C.; Căproiu, M. T.; Bădoiu, A. J. Chem. Crystallogr. 2004, 34, 577.

35. Dumitrascu, F.; Caira, M. R.; Draghici, C.; Caproiu, M. T.; Badoiu, A. Molecules 2005, 10, 321.

36. Dumitrascu, F.; Caira, M. R.; Drăghici, C.; Căproiu, M. T.; Barbu, L.; Bădoiu, A. J. Chem. Crystallogr. 2005, 35, 361.

37. Dumitrascu, F.; Drăghici, C.; Caira, M. R.; Bădoiu, A.; Barbu, L.; Cristea, M. Arkivoc 2005, $(x), 165$.

38. Dumitrascu, F.; Caira, M. R.; Draghici, C.; Caproiu, M. T. Anal. Sci. X 2007, 23, x13.

39. Caira, M. R.; Dumitrascu, F.; Barbu, L.; Dumitrescu, D. G.; Draghici, B. Rev. Chim. (Bucharest) 2007, 58, 48.

40. Dumitrascu, F.; Caira, M. R.; Drăghici, C.; Căproiu, M. T.; Barbu, L.; Miu, B. Rev. Roum. Chim. 2008, 53, 183.

41. Dumitrascu, F.; Caira, M. R.; Draghici, C.; Dumitrescu, D. G. Anal. Sci. X 2006, 22, x259.

42. Caira, M. R.; Dumitrascu, F.; Dumitrescu, D. G.; Barbu, M.; Draghici, B. Anal. Sci. X 2007, 23, x173-x174.

43. Dumitrascu, F.; Caira, M. R.; Vasilescu, M.; Barbu, L.; Drăghici, C.; Dumitrescu, D. G. Arkivoc 2007, (xvi), 101.

44. Yavari, I.; Maghsoodlou, M. T.; Pourmossavi, A. J. Chem. Res. (S) 1997, 212.

45. Maghsoodlou, M. T.; Pour, B. T.; Marandi, G.; Akbarzadeh, N. Arkivoc 2008, (ii), 153.

46. Dumitrascu, F.; Caira, M. R.; Barbu, L.; Miu, B.; Draghici, B. Anal. Sci. X 2008, 24, x27.

47. Granzhan, A.; Ihmels, H.; Mikhlina, K.; Deiseroth, H. J.; Mikus, H. Eur. J. Org. Chem. 2005, 4098.

48. Granzhan, A; Bats, J. W.; Ihmels, H. Synthesis 2006, 1549.

49. Tanaka, Y.; Sekita, A.; Suziki, H.; Yamashita, M.; Oshikawa, T.; Yonemitsu, T.; Tori-i, A. J. Chem. Soc., Perkin Trans. 1 1998, 2471.

50. Watanabe, M.; Sukuki, H.; Tanaka, Y.; Ishida, T.; Oshikawa, T.; Tori-i, A. J. Org. Chem. 2004, 69, 7794.

51. Caronna, T.; Gabiadini, S.; Mele, A.; Recupero, F. Helv. Chim. Acta 2002, 85, 1. 
52. Field, J. E.; Hill, T.; Venkataraman, D. J. Org. Chem. 2003, 68, 6071.

53. Laursen, W. B.; Krebs, F. C. Angew. Chem. Int. Ed. 2000, 39, 3432.

54. Laursen, W. B.; Krebs, F. C. Chem. Eur. J. 2001, 7, 1773.

55. Herse, C.; Bas, D.; Krebs, F. C.; Burgi, T.; Weber, J.; Wesolowski, T.; Laursen, B. W.; Lacour, J. Angew. Chem. Int. Ed. Engl. 2003, 42, 3162.

56. Laleu, B.; Mobian, P.; Herse, C.; Laursen, B. W.; Hopfgartner, G.; Bernardinelli, G.; Lacour, J. Angew. Chem. Int. Ed. Engl. 2005, 44, 1879.

57. Villani, C.; Laleu, B.; Mobian, P.; Lacour, J. Chirality 2007, 19, 601.

58. Fox, J. M.; Katz, T. J. J. Org. Chem. 1999, 64, 302.

59. Dreher, S. D.; Weix, D. J.; Katz, T. J. J. Org. Chem. 1999, 64, 3671.

60. Bell, T. W.; Jousselin, H. J. Am. Chem. Soc. 1991, 113, 6283.

61. Lebon, F.; Longhi, G.; Gangemi, F.; Abbate, S.; Priess, J.; Juza, M.; Bazzini, C.; Caronna, T.; Mele, A. J. Phys. Chem. A 2004, 108, 11752.

62. Abbate, S.; Bazzini, C.; Caronna, T.; Fontana, F.; Gangemi, F.; Longhi, G.; Mele, A.; Sora, I. N. Inorg. Chim. Acta 2007, 360, 908.

63. Granzhan, A.; Ihmels, H. ChemBioChem 2006, 7, 1031.

64. Roithova, J.; Schroder, D.; Misek, J.; Stara, I. G.; Stary, I. J. Mass Spectrom. 2007, 42, 1233.

65. Danac, R.; Constantinescu, M.; Rotaru, A.; Ghirvu, C.; Druta, I. J. Heterocyclic Chem. 2004, 41, 983.

\section{Authors' biographies}

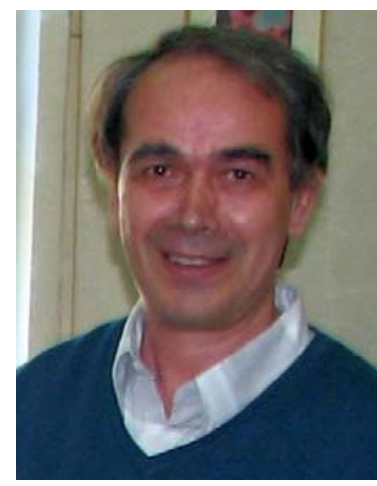

Dr. Florea Dumitraşcu was born in 1952. He graduated “Al. I. Cuza” University, Iasi, Romania in 1976. After working for 4 years in industry, he pursued his research interests at the Center for Organic Chemistry "C. D. Nenitzescu”, Romanian Academy, where he obtained his PhD in 1994. His research interests are in the fields of 1,3-dipolar cycloadditions and heterocyclic chemistry. 


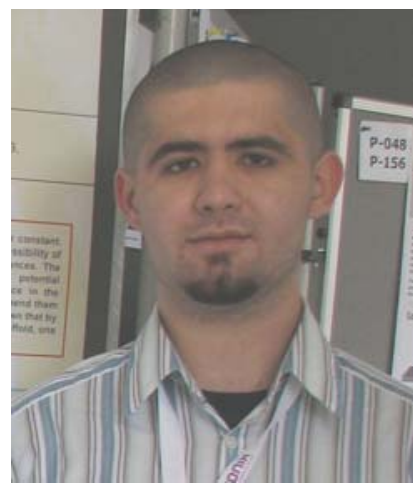

Dan George Dumitrescu graduated "Politehnica" University of Bucharest, Romania, in 2009. He has been working as a research assistant with Dr. Florea Dumitraşcu for 3 years and is currently working on the synthesis of new helical compounds and fluorescent molecules.

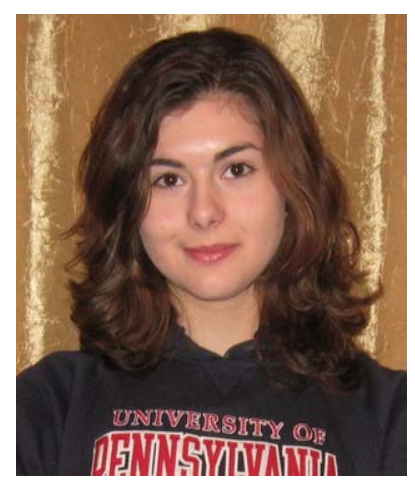

Ioana Aron is a candidate for a BA in Chemistry at the University of Pennsylvania, USA. She is currently working as an Undergraduate Research Assistant with Dr. Gary Molander, exploring the field of organotrifluoroborates. 